King \& Heise 2-15 draft

\title{
Misdemeanor Appeals
}

\author{
Nancy J. King \& Michael Heise*
}

Abstract

Misdemeanor cases affect far more people than felony cases, outnumbering felony cases by more than three to one. Yet very little empirical information exists on many aspects of misdemeanor prosecutions. This Article provides the first quantitative look at appellate review in misdemeanor cases, nationwide. It uses data drawn from a random sample of direct criminal appeals decided by every state appellate court in the nation, unpublished aggregate data on misdemeanor trial court cases provided by the Court Statistics Project, and published state court statistics.

We provide the first estimate of the rate of appellate review for misdemeanors, concluding that appellate courts review no more than eight in 10,000 misdemeanor convictions, and disturb only one conviction or sentence out of every 10,000 misdemeanor judgments. This level of oversight is much lower than that for felony cases, for reasons we explain. To develop law and regulate error in misdemeanor cases, particularly in prosecutions for the lowest-level offenses, courts may need to provide mechanisms for judicial scrutiny outside the direct appeal process.

Additional findings include new information about the rate of felony trial court review of lower court misdemeanor cases, ratios of appeals to convictions for various misdemeanor-crime categories, detailed descriptive information about misdemeanor cases that reach state appellate courts, the results of a complete statistical analysis examining which features are significantly associated with a greater or lesser likelihood of success, including crime type, claim raised, judicial-selection method, and type of representation, and the first quantitative look at how misdemeanor appeals differ from felony appeals.

\footnotetext{
* King is Speir Professor of Law, Vanderbilt University Law School; Heise is Professor, Cornell Law School. We thank Griffin Farha and Jordan Bunn for research assistance, Nicole Waters and Brittney Via from the National Center for State Courts for their assistance with data, and to our colleagues for their helpful suggestions on prior drafts.
} 
King \& Heise 2-15 draft

\section{Misdemeanor Appeals Nancy J. King \& Michael Heise*}

Misdemeanor cases dominate the criminal caseloads of state trial courts. Each year, state prosecutors charge an estimated 13.2 million defendants with assault, DUI, vagrancy, gambling, drunkenness, liquor-law violations, disorderly conduct, prostitution, vandalism, theft, drug possession, and a range of traffic offenses, such as reckless driving, speeding, eluding police, and driving with a suspended license. ${ }^{1}$ Those convicted are fined, sentenced to terms of probation, or, less frequently, sentenced to short terms of incarceration, often the "time served" waiting in jail for their cases to be resolved. ${ }^{2}$

For defendants charged with misdemeanors and their families, the hardship of fulfilling a misdemeanor sentence pales in comparison to consequences of the process itself. ${ }^{3}$ For defendants who are not convicted,

* King is Speir Professor of Law, Vanderbilt University Law School; Heise is Professor, Cornell Law School. We thank Griffin Farha for research assistance, Nicole Waters and Brittney Via from the National Center for State Courts for their assistance with data, and to our colleagues for their helpful suggestions.

1 Two different estimates of misdemeanor filings independently reached the same conclusion. See AleXandra NATAPOFF, Punishment Without Crime: How Our Massive MisdemeANOR SYstem Traps the InNOCENT AND MAKES AMERICA MoRE UNEQUAL 39-54, 251-63 (2018) (estimating 13,240,034 misdemeanor cases filed each year after collecting data from state court administrative offices, the National Center for State Courts, and other publicly available reports); Megan Stevenson \& Sandra Mayson, The Scale of Misdemeanor Justice, 98 B.U. L. REV. 731, 736-37 (2018) (estimating 13.2 million misdemeanor cases filed each year based on data from the National Center for State Courts). For a detailed breakdown of how states define misdemeanors, see 1 WAYNE R. LAFAVE ET AL., CRIMINAL PROCEDURE § 1.8(c) (4th ed. 2015).

2 See infra text accompanying note 45 (discussing research showing that many convicted misdemeanants are sentenced to "time served" and released upon sentencing).

${ }^{3}$ Professor Malcolm Feeley wrote the classic, groundbreaking authority on this topic, see Malcolm M. Feeley, The Process Is the Punishment: Handling CASES IN A Lower CRIMINAL COURT (1979), and Professor Alexandra Natapoff has added a brilliant, contemporary analysis, see NATAPOFF, supra note 1.

On collateral consequences, see MARGARET COLGATE LOVE, JENNY ROBERTS \& Wayne A. Logan, Collateral Consequences of Criminal Convictions: LaW, Policy, AND PRACTICE chs. 5-6 (2018); NATAPOFF, supra note 1, at 19-38; Eisha Jain, Proportionality and Other Misdemeanor Myths, 98 B.U. L. REV. 953, 958 (2018) (explaining that criminal-record information is now widely shared but unreliable, often containing incomplete information about whether charges were dismissed); Jenny Roberts, Informed Misdemeanor Sentencing, 46 HOFSTRA L. REV. 171, 172-73 (2017) (noting that "the often life-long effects of even a minor criminal charge have become particularly pernicious over the past decade" because of easier access to criminal history information and new laws 
missed work from detention and multiple court appearances while the charge is pending can lead to job loss and eviction, for example, and the arrest alone marks the defendant for harsher treatment should there be future criminal justice encounters. ${ }^{4}$ For those convicted, that criminal record has an impact that lasts much longer than the time it takes to satisfy the sentence itself. It can cost defendants their driver's licenses ${ }^{5}$ and voting rights, ${ }^{6}$ cripple employment opportunities, ${ }^{7}$ and end essential government benefits for housing, nutrition, and education. ${ }^{8}$ Some misdemeanor convictions lead to deportation, ${ }^{9}$ or to registration and residency restrictions as a sex offender. ${ }^{10}$ And when a defendant is unable to pay fines, fees, and costs, one of these "minor" convictions can lead to debilitating debt. 11

creating "barriers to employment, licensing, and other areas based on a person's criminal history"). For a searchable database of collateral consequences in every state for each crime, see National Inventory of Collateral Consequences of Conviction, JUsT. CTR., CoUNCIL ST. GOV’TS, https://niccc.csgjusticecenter.org/ (last visited Dec. 27, 2018) [https://perma.cc/U8Z2-U8F4].

${ }^{4}$ See Issa Kohler-Hausmann, Misdemeanorland: Criminal Courts and Social Control IN AN AGE OF BROKEn Windows Policing 183-220 (2018); NATAPOFF, supra note 1, at 20$23,34-35$.

${ }^{5}$ See LOVE, ROBERTS \& LOGAN, supra note $3, \S 2: 23$.

${ }^{6}$ See Beth A. Colgan, Wealth-Based Penal Disenfranchisement, 72 VAND L. REV. 55 (2019).

${ }^{7}$ NATAPOFF, supra note 1 , at 29. Moreover, a conviction may render a person legally ineligible to work in certain industries or positions. In Ohio, for example, a misdemeanor can eliminate the ability to obtain or maintain licenses for dozens of professional activities, including teaching, practicing law, auctioneering, embalming, and practicing cosmetology. See City of Cleveland Heights v. Lewis, 953 N.E.2d 278, 284 (Ohio 2011) (Lundberg Stratton, J., concurring).

8 See LOVE, RoBERTS \& LOGAN, supra note 3, §§ 2:16, 2:17, $2: 22$ (discussing federal food-anddrug-program debarment, access to public housing and rental subsidies, and student financial aid and other educational consequences). Government employees may lose their pensions. See, e.g., Commonwealth v. Abraham, 62 A.3d 343, 344 (Pa. 2012) (reviewing a teacher's guilty plea to an offense leading to forfeiture of his public-employee pension); LOVE, ROBERTS \& LOGAN, supra note $3, \S 2: 21$, at n.7.

${ }_{9}^{9}$ See NATAPOFF, supra note 1 , at 50 (stating that the top charge triggering deportation in Davidson County, Tennessee, in 2012 was driving without a license).

10 See LOVE, ROBERTS \& LOGAN, supra note 3, §§ 2:39, 2:51 (discussing sex-offender registration and deportability, respectively); see also United States v. Ross, 848 F.3d 1129, 1130-31 (D.C. Cir. 2017) (reviewing conditional guilty plea of defendant, previously convicted of misdemeanor sex offense, for failing to register in new state of residence); Commonwealth v. Muniz, 164 A.3d 1189, 1215 n.20 (Pa. 2017) (listing SORNA predicate offenses that may be graded as misdemeanors under Pennsylvania law: interference with custody of children; luring of a child into a motor vehicle or structure; indecent assault; invasion of privacy; and various conduct with obscene and other sexual materials and performances).

11 See, e.g., NATAPOFF, supra note 1, at 128-32 (detailing how defendants are incarcerated because they cannot afford to pay criminal debt); Note, State Bans on Debtors' Prisons and Criminal Justice Debt, 129 HARV. L. REV. 1024, 1027-30 (2016) (describing the extent of the 
A resurgence of interest in misdemeanor enforcement's huge impact on society, particularly on poor and minority communities, has fueled an explosion in new empirical research about misdemeanor arrests, ${ }^{12}$ charging, ${ }^{13}$ bail, ${ }^{14}$ counsel, ${ }^{15}$ sentencing, ${ }^{16}$ and collateral consequences. ${ }^{17}$ Yet what we know about contemporary misdemeanor-case processing remains incomplete, with gaping holes.

problem and providing several examples); see also Jenny Roberts, The Innocence Movement and Misdemeanors, 98 B.U. L. REV. 779, 820 (2018) ("[W]hile driving with a suspended license charges can make up a significant part of the caseload in many jurisdictions, the suspensions often 'result from failure to pay fines or fees, such as tickets for a broken tail light .. . parking tickets, or even failure to pay child support.'" (omission in original) (quoting Robert C. BORUCHOWITZ, MALIA N. BRINK \& MAUREEN DIMINO, NAT'L ASS'N OF Criminal Def. LaWyers, Minor Crimes, Massive Waste: The Terrible Toll of America's BROKEN MisDEMEANOR COURTS 26 (2009),

https://www.nacdl.org/WorkArea/linkit.aspx?Linkldentifier=id\&ItemID=20808 [https://perma.cc/E595-HPZB]).

12 See, e.g., Eisha Jain, Arrests as Regulation, 67 STAN. L. REV. 809, 820-25 (2015) (summarizing empirical and anecdotal data on the direct and indirect costs to arrestees).

${ }^{13}$ See, e.g., Issa Kohler-Hausmann, Managerial Justice and Mass Misdemeanors, 66 STAN. L. REV. 611, 636-37 (2014) (explaining misdemeanor-charging in New York City).

${ }_{14}$ See, e.g., Shima Baradaran Baughman, The History of Misdemeanor Bail, 98 B.U. L. REV. 837, 842-44, 873 (2018) (showing that pretrial detention of misdemeanor defendants correlates with higher guilty-plea rates, increased likelihood of incarceration in sentences, longer sentences, and higher recidivism rates, even though most misdemeanor charges are dismissed before trial); Paul Heaton, Sandra Mayson \& Megan Stevenson, The Downstream Consequences of Misdemeanor Pretrial Detention, 69 STAN. L. REV. 711 (2017) (reaching similar results in study of misdemeanor cases in Harris County, Texas). See also SHIMA BARADARAN BAUghMAN, THE BAIL BOOK: A COMPREHENSIVE LOOK AT BAIL IN AMERICA'S CRIMINAL JUSTICE SYSTEM 87-88 (2018) (detailing data on earned income for individuals in pretrial detention); Will Dobbie, Jacob Goldin, and Crystal Yang, The Effects of Pre-Trial Detention on Conviction, Future Crime, and Employment: Evidence from Randomly Assigned Judges, 108 AM. ECON. REV. 201 (2018) (evaluating data that included about 228,000 misdemeanor cases and finding detained defendants are more likely to plead guilty, to be rearrested after disposition, and to experience poor labor outcomes even years later).

15 See, e.g., Erica Hashimoto, The Problem with Misdemeanor Representation, 70 WASH. \& LEE L. REV. 1019, 1033 (2013) (summarizing aggregate data and site observations regarding right-to-counsel notice to misdemeanor defendants); John D. King, Beyond "Life and Liberty": The Evolving Right to Counsel, 48 HARV. C.R.-C.L. L. REV. 1, 21-22 (2013) (noting the "mass processing of low-level charges without significant regard for either substantive or procedural justice").

${ }^{16}$ See, e.g., Roberts, supra note 3.

17 One example of this renewed attention is a recent symposium on misdemeanor justice. See Symposium, Misdemeanor Machinery: The Hidden Heart of the American Criminal Justice System, 98 B.U. L. REV. 669 (2018). For two handy collections of recent research, see NATAPOFF, supra note 1; Alexandra Natapoff, Misdemeanors, in 1 REFORMING CRIMINAL JUSTICE 71 (Erik Luna ed., 2017), http://academyforjustice.org/wpcontent/uploads/2017/10/5_Reforming-Criminal-Justice_Vol_1_Misdemeanors.pdf [https://perma.cc/U2BH-4SPM]. 
This Article contributes new information to fill an important void. It provides the first quantitative look at appellate review in misdemeanor cases using data collected by the National Center for State Courts in its Survey of State Court Criminal Appeals ("NCSC Appeals Study")—data drawn from a random sample of direct criminal appeals decided by every state appellate court in the nation. ${ }^{18}$ To provide additional context, we also reference unpublished aggregate data about misdemeanor cases in state trial courts provided to us by the Court Statistics Project ("CSP") 19 and published state court statistics on trial court review of lower court misdemeanor adjudication. ${ }^{20}$ We examine how misdemeanor prosecutions in trial courts compare to the cases that reach appellate courts, what claims of error state appellate courts actually review, and which factors are associated with the likelihood of success for defendants who appeal from misdemeanor judgments, including crime type, claim raised, judicial-selection method, and type of representation. We also provide the first quantitative look at how misdemeanor appeals differ from felony appeals.

Our Article unfolds as follows. Part I reviews the legal framework for misdemeanor appeals and summarizes existing empirical scholarship on these appeals. We estimate that, at most, approximately eight in 10,000 misdemeanor judgments are appealed and lay out the reasons why the level of review is so much less than in felony cases, including an empirical examination of appeals to trial courts in two-tier trial court systems, a subject unaddressed by existing literature.

Part II explains our primary research questions. First, which misdemeanor cases reach appellate courts (and which do not)? Second, what factors correspond with a higher likelihood of success for the appeals that are filed? And third, how do misdemeanor appeals differ from felony appeals? Part III describes our data and the empirical strategy that we use to investigate these questions.

Part IV presents our findings for all three research questions. Based on data from about a third of the states, appellate courts do on average review cases from all general misdemeanor crime categories, but the case mix is

\footnotetext{
18 See Nicole L. Waters et Al., U.S. DeP’T of Justice, Bureau of Justice Statistics, CRIMINAL APPEALS IN STATE COURTS 4-5 (2015), https://www.bjs.gov/content/pub/pdf/casc.pdf [https://perma.cc/AAK3-58WR] [hereinafter NCSC APPEALS STUDY] (examining direct appeals but not interlocutory appeals, appeals involving writs, appeals in proceedings for post-conviction relief, or appeals of probation and parole revocation decisions). For other articles based on the NCSC Appeals Study, see Michael Heise, Nancy J. King \& Nicole A. Heise, State Criminal Appeals Revealed, 70 VAND. L. REV. 1939 (2017) [hereinafter Heise, King \& Heise, State Criminal Appeals]; Nancy J.

King \& Michael Heise, Appeals by the Prosecution, 15 J. EMPIRICAL LEGAL STUD. 482 (2018) [hereinafter King \& Heise, Appeals by the Prosecution].

19 See infra note 55.

20 See infra note 40.
} 
skewed compared to the mix in trial courts. Compared to trial courts, appellate judges see a larger percentage of violent and DUI offenses and a much lower percentage of non-DUI driving offenses. As for factors associated with success on appeal, appeals by prosecutors, appeals in sex crime and nonDUI driving offenses were more likely to succeed, but other factors, such as the presence of oral argument, a reply brief, judicial selection method, claim type, or type or representation, made no significant difference in the likelihood of a favorable outcome. Compared to felony appellants, misdemeanor appellants had similar success rates, but a larger proportion had retained counsel or no legal representation at all. Part V concludes with potential policy implications.

\section{Misdemeanor Appeals: Rate of Appeal, Legal Framework, and Existing Research}

This section provides a foundation for the research questions we investigate by summarizing the law regulating misdemeanor appeals, relevant aspects of misdemeanor case processing, and pertinent existing research. It begins with a look at the ratio of misdemeanor appeals to misdemeanor convictions in trial courts, a ratio much lower than that for felonies, and a review of explanations for that difference. The section concludes with a summary of the meager empirical research on misdemeanor appeals and the contributions of this study.

\section{A. How many of the misdemeanor cases processed in state trial courts reach appellate courts?}

Although misdemeanor cases constitute roughly three quarters of all criminal cases filed in state trial courts, ${ }^{21}$ the level of judicial review of final judgments in these cases is vanishingly small. The actual rate at which misdemeanor defendants appeal requires estimation because statewide statistics on the conviction rate for misdemeanor cases are available for only 16 states and the District of Columbia. Only five of those jurisdictions report conviction or guilty plea rates under 50 percent. ${ }^{22}$ (Guilty pleas roughly

\footnotetext{
${ }^{21}$ Stevenson \& Mayson, supra note 1, at $746 \&$ n.81. Professor Natapoff estimates misdemeanors compose closer to 80 percent of criminal dockets. See NATAPOFF, supra note 1 , at 2 . States vary greatly in defining what crimes count as misdemeanors, complicating even the most basic attempt to count the number of misdemeanor cases charged or filed. See id. at 45-48, 254-55; Stevenson \& Mayson, supra note 1, at 738-40. The key difficulty is in how states classify various traffic offenses. An infraction or violation in one state may be a misdemeanor in another. Because the number of traffic cases filed in state courts each year is so large, dwarfing other misdemeanor-offense categories, this classification decision can significantly affect misdemeanor research.

${ }^{22}$ For the derivation of conviction rates, see Appendix B (listing estimated rates: Alaska 57\%; California 70\%; District of Columbia 37\%; Florida 59\%; Hawai'i 55\%; Indiana 54\%;
} 
approximate convictions in most states, since only 1-2 percent of misdemeanor convictions follow a trial, with 98-99 percent of convictions coming after guilty plea. ${ }^{23}$ ) With so much missing information, estimating an accurate national misdemeanor conviction rate is perilous. However, to place misdemeanor appeals into perspective, a conservative estimate will do. Multiplying a conviction rate of only 40 percent by the estimated 13.2 million misdemeanor cases filed in 2016, ${ }^{24}$ and adding an estimated 528,000 additional misdemeanor convictions resulting from felony charges, ${ }^{25}$ generates a conservative estimate of approximately 5.8 million misdemeanor convictions entered by state courts nationwide in 2016 .

Estimating the number of misdemeanor direct appeals filed in state appellate courts requires less conjecture, thanks to the primary data source we examine in this Article. Collected by researchers at the NCSC from a random sample of 2010 decisions by state appellate courts nationwide, and released to the public in 2016, the NCSC Appeals Study is the only existing systematic nationwide source of empirical information about direct appeals in

Kansas 54\%; Michigan 39\%; Missouri 65\%; New Mexico 50\%; New York 54\%; North Carolina 31\%; Ohio 45\%; Texas 65\%; Vermont 55\%; Washington $42 \%$; Wisconsin $72 \%$ ).

In addition, misdemeanor conviction rates were available for the following local jurisdictions: Cook County, Illinois 56\%; Hennepin County, Minnesota 56\%; Philadelphia, Pennsylvania and Miami, Florida averaged together, 54\%. Local jurisdictions may vary substantially from statewide rates. See, e.g., KoHLERHAUSMANN, supra note 4, at 69 (finding conviction rate in New York City of 19.5 percent).

${ }^{23}$ E.g., 1 LAFAVE ET AL., supra note $1, \S 1.11$ (c-1) (4th ed. Supp. 2017-2018) (noting trial rates almost uniformly below 2 percent in more than a dozen states reporting disposition information for at least some misdemeanors); see also BRIAN A. REAVES, U.S. DEP'T OF Justice, Bureau of Justice Statistics, Felony Defendants in LaRge URban Counties, 2009 - STATISTICAL TABLES 24 tbl.21 (2013), https://www.bjs.gov/content/pub/pdf/fdluc09.pdf [https://perma.cc/XZ23-GE4R] (reporting more than 99 percent of felony charges that ended in misdemeanor convictions were by plea, not trial).

The CSP lists 2017 bench and jury trial rates-but not whether those trials ended in conviction or acquittal-for misdemeanor dispositions in nineteen states. Combining these states (except North Carolina, which reported an anomalous 32 percent bench trial rate, and Iowa, which reported only bench but not jury trial rates) only 2.23 percent of misdemeanor cases ended in either acquittal or conviction after trial. See Nat'l Ctr. for State Courts \& Conference of State Court Adm'rs, CSP DataViewer, CT. STAT. PROJECT, http://popup.ncsc.org/CSP/CSP_Intro.aspx (last visited Dec. 28, 2018) [https://perma.cc/7CMS-YL9B] [hereinafter CT. STAT. PROJECT].

${ }^{24}$ See supra text accompanying note 1.

${ }^{25}$ BJS reports that in 2009, approximately 12 percent of felony case filings in the seventyfive largest counties in the country ended in misdemeanor convictions. REAVES, supra note 23, at 24 tbl.21; see also 1 LAFAVE ET AL., supra note1, § 1.11(c-1) (4th ed. Supp. 2017-2018) (reporting multiple states' rates at which felony charges are reduced to misdemeanor convictions, as a percentage of total convictions for felony charges, ranging from 8-23 percent). Twelve percent of roughly 4,400,000 annual felony filings in state court equals an estimated 528,000 misdemeanor convictions resulting from felony charges. 
state criminal cases, including misdemeanors. The only published information about the sample of misdemeanor appeals in the NCSC Appeals Study appears in a Bureau of Justice Statistics ("BJS") Bulletin. ${ }^{26}$ That Bulletin summarizes a handful of aggregate statistics and estimates the number of direct appeals decided in misdemeanor cases nationwide in 2010 to be about 5,300, about 7.0 percent of all direct criminal appeals decided by intermediate appellate courts, and 9.4 percent of all direct criminal appeals decided by courts of last resort. ${ }^{27}$ Comparing this appeals rate with a conservative estimate of the number of convictions from misdemeanor filings in $2010^{28}$ produces a ratio of about eight appeals for every 10,000 misdemeanor convictions in state trial courts, or one in 1,250.29 This rate of activity at the appeals court level in state misdemeanor cases is substantially lower than the rate in state felony cases. Available information suggests one in every seventeen to forty-five convicted felons files an appeal. ${ }^{30}$

${ }^{26}$ NCSC APPEALS STUDY, supra note 18, at 10.

${ }^{27}$ See id. at 4 tbl.1, 5 tbl.2. A study of federal court cases from 1999 suggested a rate of appeal for misdemeanor convictions closer to 5 percent. See JoHn SCALIA, U.S. DEP'T OF Justice, Bureau of Justice Statistics, Federal Criminal ApPeals, 1999 With Trends 1985-1999, at 2-3 (2001), https://www.bjs.gov/content/pub/pdf/fca99.pdf

[https://perma.cc/EY3S-DAYX] (finding that "[d]efendants convicted of property, immigration, and misdemeanor offenses were among the least likely to file an appeal," and that defendants filed five appeals for every 100 convictions in misdemeanor cases).

28 Misdemeanor filings have been trending downward. In 2010 approximately 15.3 million misdemeanor cases were filed in state trial courts. See Stevenson \& Mayson, supra note 1, at 747 fig.1. Assuming 40 percent of these 2010 misdemeanor filings resulted in convictions $(6,120,000)$, and adding an estimated 528,000 additional misdemeanor convictions from felony charges, see supra note 25 , produces an estimated 6,648,000 misdemeanor convictions in 2010 .

${ }^{29}$ A less conservative estimated conviction rate of 60 percent instead would produce a ratio of only 5.8 appeals for every 10,000 convictions.

30 The NCSC Appeals Study reported state appellate courts decided roughly 55,600 felony direct appeals in 2010. NCSC APPEALS STUDY, supra note 188, at 4 tbl.1, 5 tbl.2.

Somewhere between 1.1 and 2.38 million state felony convictions are entered each year. The lower bound comes from SEAN RosenMerkel, MATTHEW Durose \& DONALD FAROLE, JR., U.S. DeP'T of Justice, BuREau of Justice Statistics, Felony SENTEnCES in State COURTS, 2006 - STATISTICAL TABLES 3 tbl.1.1 (2009), https://www.bjs.gov/content/pub/pdf/fssc06st.pdf [https://perma.cc/PJQ6-ZJNF] (estimating state courts convicted and sentenced 1.13 million people for felony offenses in 2006). The higher 2.38 million estimate is derived by dividing 13.2 million annual state misdemeanor filings, see supra note 1 , by three, the consistent felony-to-misdemeanor-caseload ratio in state courts nationwide over several years, see NAT'L CTR. FOR STATE COURTS, STATE COURT CASELOAD DiGEST 11-12 (2016), http://www.courtstatistics.org/ /media/microsites/files/csp/national-overview2016/sccd_2016.ashx [https://perma.cc/LZ8J-WYXP]; Stevenson \& Mayson, supra note 1, at 746-47, $746 \mathrm{n} .81,764$, then multiplying those 4.4 million annual felony filings by a conviction rate of 54 percent, see REAVES, supra note 23, at 24 tbl.21 (reporting 2009 conviction rate of 54 percent for felonies in the seventy-five largest counties). 


\section{B. Why so few misdemeanor appeals?}

One partial explanation for the much lower ratio of appeals to convictions in misdemeanor cases as compared to felony cases is that some states specially restrict misdemeanor appeals. For example, some states that provide felony defendants the right to appellate review deny that same right to misdemeanor defendants; instead, these states provide only appeal at the discretion of the court. ${ }^{31}$ Or a state may reserve high court review for felony cases and limit judicial review in misdemeanor cases to intermediate appellate courts. ${ }^{32}$

Another legal constraint depressing the number of misdemeanor appeals is the two-tier trial court structure in many states. Unlike states with a single trial court, from which misdemeanor and felony defendants alike may appeal directly to an appellate court, ${ }^{33}$ states with a two- or multiple-tier trial court structure adjudicate at least some misdemeanors in a trial court of limited jurisdiction, while felonies are handled by the state's trial court of general jurisdiction or "felony trial court." 34 In most of these states, defendants must challenge misdemeanor judgments from the lower courts in the felony trial court, at least initially, instead of appealing directly to the appellate courts. In some states, the appeal to the felony trial court is "de novo"; that is, the prosecution begins again with the opportunity for new plea

${ }^{31}$ For a fifty-state summary, see Bundy v. Wilson, 815 F.2d 125, 136-42 (1st Cir. 1987).

32 See, e.g., McMonagle v. Meyer, 802 F.3d 1093, 1096 (9th Cir. 2015) (noting

misdemeanants may not appeal to the California Supreme Court); Batey v. Dare, 742 So. $2 \mathrm{~d}$ 194, 196 (Ala. Civ. App. 1999) (explaining that the Alabama Court of Criminal Appeals has "exclusive appellate jurisdiction of all misdemeanors" (internal quotation marks omitted) (quoting AlA. CODE § 12-3-9 (1999))).

${ }^{33}$ For example, all criminal judgments of the only state-equivalent trial court in the District of Columbia, the D.C. Superior Court, are appealed to the D.C. Court of Appeals. See D.C. CODE $§ 11-721$ (2018). Illinois and Minnesota also have unified trial courts. See ILL. SuP. CT. R. 603; MINN. R. CRIM. P. 28.

${ }^{34}$ For a state-by-state listing of the jurisdiction of courts of limited jurisdiction, see Nat'l Ctr. for State Courts \& Conference of State Court Adm'rs, State Court Structure Charts, CT. STAT. PROJECT, http://www.courtstatistics.org/Other-

Pages/State_Court_Structure_Charts.aspx (last visited Dec. 29, 2018)

[https://perma.cc/2GPX-5ZD4]. See also U.S. DeP’T OF Justice, BuREAU OF Justice

StATiSTICS, STATE COURT ORGANIZATION 2004, at 265-319 (2006), https://www.bjs.gov/content/pub/pdf/sco04.pdf [https://perma.cc/K5J5-JA37]. For a listing of the appellate jurisdiction of state trial courts as of 2010, see Nat'l Ctr. for State Courts \& Conference of State Court Adm'rs, State Trial Courts with Incidental Appellate Jurisdiction, 2010, CT. STAT. PROJECT (2012),

http://www.courtstatistics.org/ /media/Microsites/Files/CSP/SCCS/2010/State_Trial_Courts _with_Incidental_Appellate_\%20Jurisdiction.ashx [https://perma.cc/S586-3LSY]. 
negotiations or trial. ${ }^{35}$ In others, the felony trial court conducts ordinary appellate review based solely on the lower court record, so that an appeal to the state's appellate courts would be a second review of that record.

These two-tier trial court structures reduce the rate at which misdemeanor cases reach appellate courts. In at least three states with a twotier system, a misdemeanor defendant is barred from further appealing the felony trial court's decision to an appellate court. ${ }^{36}$ In others, a defendant may seek review of the felony trial court's decision regarding a misdemeanor judgment, but only by permission. ${ }^{37}$ Even where appeal from the felony trial court to the state appellate court is by right, reaching the appellate court requires an extra appeal, twice the effort a felony defendant must expend. ${ }^{38}$

Based on estimates from the very limited statistics available, few misdemeanor defendants seek even one appeal to the next-level trial court in these two-tier states. Of the thirteen states that separate misdemeanor appeals from original criminal filings in the trial court statistics they report, in all but one, the estimated ${ }^{39}$ ratio of appeals to lower court convictions was

35 This is commonly required if the lower court proceeding was not on the record or the lower court judge was not a lawyer. See 1 LAFAVE ET AL., supra note 1, § 1.4(j); 6 id. $\S 22.1(\mathrm{f})$.

${ }^{36}$ In Alaska, Arizona, and New Hampshire, seeking review in the felony trial court precludes review in the appellate court that ordinarily reviews trial court judgments. See ALASKA STAT. § 22.07.020(d)(1) (2018) ("[T] he right of appeal to the court of appeals is waived if an appellant chooses to appeal the final decision of the district court to the superior court ... ."); State v. Eby, 244 P.3d 1177, 1178-79 (Ariz. Ct. App. 2011) (confirming right to appeal judgment of justice court to superior court but no right to subsequent appeal to Arizona Court of Appeals, even when superior court appeal is a de novo trial); State v. Thompson, 83 A.3d 388, 391 (N.H. 2013) (holding statute "does not allow a defendant to pursue both avenues of appeal, either simultaneously or consecutively").

37 See, e.g., Mich. Ст. R. 7.203(B)(2) (allowing Michigan Court of Appeals to grant leave for party to appeal judgment of circuit court in case on appeal from another court);

Commonwealth v. Hurd, 612 S.W.2d 766, 768 (Ky. Ct. App. 1981) ("There is no appeal as a matter of right to the Court of Appeals from an appellate decision of the circuit court. Such review can only be had by a motion for discretionary review ....").

${ }^{38}$ See, e.g., State v. Morel, 673 So. 2d 1291, 1292 (La. Ct. App. 1996) (remanding appeal of misdemeanor convictions to felony trial court because there is no direct appeal to courts of appeal); Parks v. State, 194 So. 3d 179, 180-81 (Miss. Ct. App. 2015) (observing court rule that requires notice of appeal and both appearance bond and cost bond to be filed with circuit clerk within 30 days of date of conviction in either justice court or municipal court); Sparks v. Bare, 373 P.3d 864, 868 (Nev. 2016) (holding felony trial court may require a nonindigent misdemeanor appellant to obtain and pay for transcripts for a misdemeanor appeal); $c f$. Roberts, supra note 11, at 828-29 ("[T] he process costs of fighting a misdemeanor case are high, prohibitively so for many people.").

${ }^{39}$ Because most of these states' reports did not identify the number of convictions, determining what proportion of these appellate dispositions were from lower court convictions required an estimation. When necessary, we estimated that 50 percent of total misdemeanor dispositions in the lower trial court were convictions. See supra note 22. Information on the sources for these estimates is available by request. 
less than one in one hundred. ${ }^{40}$ Likely most of these appeals were not successful. Only two states reported dispositions of these appeals in a form that identified how many succeeded or failed. Of de novo misdemeanor appeals filed in Missouri trial courts in 2017, 81 percent resulted in guilty pleas; in New Mexico, 74 percent of misdemeanor appeals resulted in conviction.

In addition to the circumstances reviewed above, which combine to reduce generally the number misdemeanor appeals filed in appellate courts, it is important to recognize factors that depress appellate activity in the segment of misdemeanor cases that carry the lowest penalties, variously categorized as "criminal infractions," "fine-only misdemeanors," "nonindictable misdemeanors," or "Class C misdemeanors." These factors include (1) express legal restrictions on appeal in these specific cases; (2) weaker incentives for defendants convicted of these crimes to appeal; (3) the absence of counsel; and (4) higher rates of guilty pleas.

The law in several jurisdictions offers fewer opportunities for defendants to appeal these less serious misdemeanors. A state may deny the right to appeal lower-level misdemeanors entirely, ${ }^{41}$ provide appeal to a trial

${ }^{40} \mathrm{By}$ state, for the latest year available, these ratios were as follows: Arizona, 0.27 percent (578 appeals to superior courts compared to 211,521 convictions in justice and municipal courts in 2017); California, 0.12 percent (3,117 appeals to appellate division of superior courts compared to $2,697,705$ convictions in the limited jurisdiction division of superior courts in 2017); Florida, 0.27 percent (455 appeals to circuit courts compared to 170,420 convictions in county courts in FY 2017); Kentucky, 0.09 percent (175 appeals to circuit courts compared to 187,597 convictions in district court in 2017); Maryland, 6.87 percent (2,611 appeals to circuit courts compared to 38,033 convictions in district courts in 2017); Michigan, 0.09 percent (236 appeals to circuit courts compared to 256,317 convictions in district courts in 2017); Missouri, 0.47 percent (1,645 appeals to circuit courts compared to 349,408 convictions in municipal courts in 2017); Nevada, 0.27 percent (159 appeals to district courts compared to 58,483 convictions in justice and municipal courts in 2017); New Mexico, 0.84 percent (532 appeals compared to 63,339 convictions in magistrate courts in 2017); New Jersey, 0.13 percent (547 appeals to superior courts compared to 426,230 nontraffic convictions in municipal courts in $2017-18)$; Texas, 0.87 percent (28,666 appeals to county courts compared to $3,313,590$ convictions in justice and municipal courts in FY 2016-17); West Virginia, 0.67 percent (158 appeals filed in circuit courts compared to an estimated 23,659 nontraffic convictions in magistrate courts in 2017); Wyoming, 0.61 percent (58 appeals filed in district courts compared to an estimated 9,550 convictions in circuit courts in 2017). Data sources are available by request.

Available information from Utah reports a slightly different data point but reaches a similar outcome as the states above. See Sixth AmEndment CTR., THE Right To Counsel IN UTAH: AN ASSESSMENT OF TRIAL-LEVEL INDIGENT DEFENSE SERVICES, at v (2015), https://sixthamendment.org/6ac/6AC_utahreport.pdf [https://perma.cc/3HSB-FJN9] (reporting that of 79,730 total misdemeanors heard in all justice courts statewide in 2013 , only 711 of such cases were reviewed de novo in district courts, an appellate rate of 0.89 percent).

${ }^{41}$ E.g., DEL. CodE ANN. tit. 11, § 5301 (2018) (granting appeal of right only for cases, as required by state constitution, involving sentences of more than one month in jail or fines greater than \$100); Peters v. State, 943 P.2d 418, 420-21 (Alaska Ct. App. 1997) (no appeal 
court of general jurisdiction but not to an appellate court, ${ }^{42}$ or require leave to appeal instead of providing a right to appeal. ${ }^{43}$ In such states, the misdemeanor appeals that reach appellate courts are less likely to include the least serious crimes.

Sentencing practices can also affect appeal rates in misdemeanor cases, both overall appellate activity and the mix of cases that reach appellate courts. Defendants serving probation and incarceration terms would be more likely to appeal, while defendants convicted and sentenced for less serious misdemeanors and those released upon conviction or sanctioned with fines alone may have little immediate incentive to appeal their convictions before filing deadlines expire. ${ }^{44}$ Although no nationwide statistics on misdemeanor sentences in state courts exist, research reported for individual jurisdictions suggests that only a minority of those convicted of misdemeanors receive incarceration terms, and of them, a large portion are sentenced to "time served" and are released upon sentencing. ${ }^{45}$

of misdemeanor sentence unless the aggregate unsuspended terms imposed on all counts exceed 120 days).

42 McDonald v. State, 257 S.W. 889, 889 (Tex. Crim. App. 1924) (allowing defendant to appeal misdemeanor conviction to county court but dismissing second appeal from county court to Court of Criminal Appeals because fine did not exceed \$100).

${ }^{43}$ In Iowa, defendants do not have a right to appeal simple misdemeanor and ordinanceviolation convictions; instead, only discretionary review may be available. See IowA CoDE $\S 814.6$; (2018); Vance v. Iowa Dist. Court, 907 N.W.2d 473, 479-80 (Iowa 2018). Similarly, in the District of Columbia, review is only by application for the allowance of an appeal for judgments in the Criminal Division of the Superior Court where the penalty is a fine of less than fifty dollars for an offense punishable by imprisonment of one year or less, or by fine of not more than one thousand dollars, or both. See D.C. CoDE $§ 11-721$ (c) (2018); see also State v. Castillo, 57 So. 3d 1012, 1013-14 (La. 2011) (confirming Louisiana law that defendants have no right of direct appeal from convictions in bench trials, which are mandatory for misdemeanors punishable by six months or less).

44 See Roberts, supra note 3, at 189 (stating jail sentences are likely completed before any appeal would be decided, and that many learn "their seemingly minor misdemeanor conviction is actually a significant barrier to essentials of daily life such as securing housing or employment, [but] by that point the time to file a direct appeal has long expired") (citation omitted); Roberts, supra note 11, at 812 (discussing low likelihood that alien convicted of drug possession misdemeanor would know, in time to file direct appeal, that such conviction leads to mandatory deportation under federal immigration law); see also State v. Parnell, 905 N.W.2d 895, 898 (Minn. Ct. App. 2017) (applying thirty-day appeal deadline for misdemeanor conviction, not ninety-day deadline for gross misdemeanors, and dismissing appeal because defense counsel missed deadline).

${ }^{45}$ For example, North Carolina's Sentencing Commission reports sentences for a segment of the most-serious misdemeanor convictions, excluding convictions by magistrates, lower traffic offenses, ordinance violations, and DWIs. See REBECCA DiAL, JoHn KING \& JENNIFER Wesoloski, N.C. SEntencing \& Policy Advisory Comm’n, Structured SEntencing STATISTICAL REPORT: FISCAL YEAR 2017, at 33 (2018), https://www.nccourts.gov/assets/documents/publications/statisticalrpt_fy16-17.pdf [https://perma.cc/UN2M-9YRM]. In fiscal year 2017, among this set of more-serious misdemeanors, only 32 percent of defendants received incarceration sentences, which 
A third factor suggesting that the misdemeanor cases that do reach appellate courts probably underrepresent lower-level crimes is a lack of access to counsel in trial court proceedings. Many indigent misdemeanor defendants do not have attorneys to advise them that they have a right to appeal or to help them comply with the requirements for filing an appeal, and in some jurisdictions, judges reportedly fail to inform many misdemeanor offenders that they may appeal. ${ }^{46}$ The U.S. Constitution does not guarantee counsel for an indigent criminal defendant charged with a misdemeanor if the sentencing includes financial sanctions but no probation or incarceration. ${ }^{47} \mathrm{~A}$ right to

averaged thirty-four days, nineteen of which were already served, leaving fifteen days left to serve. Id. at 38, 42 tbl.18. Roughly 18 percent of these misdemeanants received monetary sanctions with no probation. Id. at 41 tbl.17, 48 .

More information about misdemeanor sentences appears in Bureau of Justice Statistics research on felony defendants in the nation's seventy-five largest counties. See REAVES, supra note 23. Among defendants initially charged with a felony but ultimately convicted of a misdemeanor instead, only about half (56 percent) received any sort of incarceration (including time served), one-third of whom (34 percent) received a sentence of a month or less, with a median sentence of three months. Id. at 29 tbl.24, 31 tbl.26. Of these reduced-from-felony

misdemeanants, 31 percent received probation (with median term of one year), and 13 percent were sentenced with financial sanctions alone. Id. at 29 tbl.24, 31 tbl.27. The sentences for a more representative pool of misdemeanor convictions that were originally charged as misdemeanors would undoubtedly be less severe, with an even smaller percentage receiving incarceration sentences.

Since misdemeanor incarceration sentences tend to be over at or shortly after conviction, some defendants who do manage to challenge their convictions before the filing deadline may find their appeals dismissed as moot if they fail to seek or are denied a stay of sentence. E.g., State v. Briggs, 86 N.E.3d 9, 14 (Ohio Ct. App. 2017); cf. Nelson v. Colorado, 137 S. Ct. 1249, 1257 n.13 (2017) (noting that state admitted at oral argument that few defendants can meet the requirements for a stay pending appeal and citing court rule that allows trial court to order defendant to deposit the whole or any part of fines and costs pending appeal). This rule has been changed only recently in some states. See, e.g., State v. Kiese, 273 P.3d 1180, 1195 (Haw. 2012) (applying a public-interest exception to the mootness doctrine and considering denial of stay of misdemeanor sentence of six months of probation pending appeal because denial of stay could affect many petty misdemeanor defendants and was likely to recur in future).

${ }^{46}$ Professor Jenny Roberts has surmised that "individuals who plead guilty in the fastpaced, high-volume lower criminal courts may not even be aware of the right to appeal, or of the need to file a notice of appeal within a short time period after conviction." See Jenny Roberts, Why Misdemeanors Matter: Defining Effective Advocacy in the Lower Criminal Courts, 45 U.C. DAVIS L. REV. 277, 337 (2011). Indeed, a report on indigent defense in Florida's lower courts found that "[a]fter sentencing at arraignment, only $23.7 \%$ of defendants were advised of their right to an appeal, and only $23.2 \%$ the right to an attorney for that appeal," despite the Florida Rules of Criminal Procedure requiring trial judges to inform defendants of their right to appeal. Id. at $337 \mathrm{n} .257$ (alteration in original); see also Roberts, supra note 3, at 189 (proposing that appellate activity in misdemeanor cases is lessened by lack of counsel and failure of judges to inform the defendant of the right to appeal, among other things).

${ }^{47}$ Alabama v. Shelton, 535 U.S. 654, 661-62 (2002); 3 LAFAVE ET AL., supra note 1, § 11.2(a). 
appointed counsel in at least some of these cases is nevertheless provided by some states, such as California, where there is a right to counsel for defendants punished by fines over $\$ 500.48$ Yet even when a defendant has a legal right to counsel, he may not actually receive counsel. Research suggests that in many lower courts handling misdemeanors, appointment as well as waiver of counsel practices discourage representation. ${ }^{49}$ Nationwide in 2002 , of defendants serving misdemeanor sentences in jail (all of whom were constitutionally entitled to counsel), 30 percent said they were not represented by counsel before conviction. ${ }^{50}$ Presumably, the representation rate was even lower for defendants sentenced to fines alone and thus not constitutionally entitled to counsel. With no lawyers to assist, the lowest-level misdemeanor defendants are less likely to file an appeal. ${ }^{51}$

48 See Shelton, 535 U.S. at 668-70 ("Most jurisdictions already provide a state-law right to appointed counsel more generous than that afforded by the Federal Constitution."); 3 LAFAVE ET AL., supra note $1, \S 11.2(\mathrm{a})$, at 697 n.35 (listing five additional states providing counsel for cases involving certain fine amounts); Request for Court-Appointed Lawyer in Misdemeanor Appeal, CAL. CTS., www.courts.ca.gov/documents/cr133.pdf (last visited Jan. 1, 2019) [https://perma.cc/Y82K-4V79].

${ }^{49}$ See id. at 1033-34, 1038 (terming practices "perhaps unconstitutional" and noting jurisdictions where courts accept waivers without sufficiently advising defendants of their right to counsel, tell defendants that their cases will be delayed if they request counsel, or insist the defendant pay a fee before they can apply for court-appointed representation; and quoting one state supreme court chief justice that her state does not comply with Shelton); Jain, supra note 3, at 959-60 (explaining that defendants choose to waive counsel and plead as quickly as possible to avoid repeated postponements in overcrowded dockets). Moreover, laws authorizing courts to order reimbursement of indigent-counsel costs from those convicted may impact misdemeanor defendants more than felony defendants, adding to the criminal debt burdens described supra note 11. See Beth A. Colgan, Paying for Gideon, 99 IOWA L. REV. 1929, 1931-39 (2014) (describing the practice of charging indigent defendants for the cost of counsel, with interest, and incarcerating them if they remain too poor to pay); Hashimoto, supra note 15, at 1033-34; see also RoBERT C. BORUCHOWITZ, MALIA N. BRINK \& Maureen Dimino, Nat'L Ass'n of Criminal Def. LaWyers, Minor Crimes, Massive Waste: The Terrible TOll OF AMERICA's BROKEn MisdemeANor CourTs 18-20 (2009), https://www.nacdl.org/WorkArea/linkit.aspx?Linkldentifier=id\&ItemID=20808 [https://perma.cc/E595-HPZB] (advocating for a "default in favor of the appointment of counsel," without delay or application fee).

${ }^{50}$ See Hashimoto, supra note 15, at 1024-26 (citing a Bureau of Justice Statistics survey sampling local-jail inmates incarcerated for misdemeanors in 2002, in which 30 percent of inmates reported that they were not represented). The numbers were similar six years earlier. CAROLINE WOLF HARlOW, U.S. DeP'T OF JUSTICE, BUREAU OF JUSTICE STATISTICS, DefEnse COUNSEl In CRIMINAL CASES 3 tbl.2, 6 tbl.13 (2000), https://www.bjs.gov/content/pub/pdf/dccc.pdf [https://perma.cc/NT6N-LF22] (reporting that in 1996, more than 28 percent of state misdemeanor defendants serving a jail sentence lacked counsel before conviction, as did more than 38 percent of federal misdemeanor defendants, also reporting that in 1996, 15 percent of state-jail inmates hired private counsel, and in 1998, 19 percent of federal defendants reported doing so)

51 This hypothesis is consistent with Tyler Buller's finding that, of 275 appeals by defendants who were represented, only nine were "simple" (as opposed to "serious" or "aggravated") misdemeanors. Tyler J. Buller, Public Defenders and Appointed Counsel in 
Finally, defendants convicted by guilty plea seek judicial review at a lower rate than those convicted after trial, for many reasons, and defendants convicted of the lowest-level misdemeanors may be even more likely to plead guilty than defendants facing more serious charges. By pleading guilty, defendants inherently waive many challenges to their conviction and often expressly agree to waive other claims, including challenges to sentence. ${ }^{52} \mathrm{~A}$ plea agreement may include a favorable charge or sentencing concession that a defendant would forfeit by filing an appeal. State law may also expressly require misdemeanor defendants who plead guilty, but not those who are convicted after trial, to obtain permission to appeal. ${ }^{53}$ All of these factors that depress appeal rates in the largest and least serious category of misdemeanor convictions-limitations on the right to appeal; weaker incentives; lack of counsel; and fewer trials - suggest far fewer of these cases will ever be reviewed.

\section{Empirical information about misdemeanor appeals beyond volume}

Beyond the total number of misdemeanor appeals, available empirical information drops off precipitously. The BJS Bulletin discussed earlier reported just three descriptive statistics concerning misdemeanor appeals filed in state appellate courts:

(1) the rate of merits review (37.9 percent in last-resort courts and

87.8 percent in intermediate appellate courts)

(2) the rate of reversal (8.3 percent in courts of last resort, and 14.8 percent in intermediate appellate courts)

(3) duration (median misdemeanor appeal lasted 1.0 years, and 95th percentile lasted 2.3 years) ${ }^{54}$

Other than these basic statistics, which aggregate prosecutor and defense misdemeanor appeals together, published sources provide hardly any information at all about the nature, processing, or success of misdemeanor appeals in state appellate courts. The CSP of the National Center for State Courts provides helpful data on all criminal appeals in state appellate courts but does not report information on misdemeanor appeals separately from

Criminal Appeals: The Iowa Experience, 16 J. APP. PRAC. \& Process 183, 247 tbls.15 \& 16, 248 tbls. $17 \& 18$ (2015). Because he did not include appeals by unrepresented appellants in his study, the number of pro se misdemeanor appeals in simple misdemeanors in Iowa appellate courts during the same period is unknown. See id. at 186 n.11.

${ }^{52}$ Class v. United States, 138 S. Ct. 798, 803 (2018); 7 LAFAVE ET AL., supra note 1, § 27.5(c).

${ }^{53}$ E.g., Russell v. State, 74 S.W.3d 887, 890 (Tex. App. 2002) (confirming Texas law that allows appeal from plea-bargained misdemeanor conviction only if trial court grants permission or appeal is based on issue raised by written pretrial motion); LAFAVE ET AL., supra note $1, \S 27.5(\mathrm{c})$, at $85 \mathrm{nn} .53-54$ (collecting authority).

54 NCSC APPEALs STUDY, supra note 18, at 4 tbl.1, 5 tbl.2, 9 fig. 8. 
felony appeals. ${ }^{55}$ Individual states may report the number, duration, and limited disposition information about criminal appeals, but few separate misdemeanor appeals from felony appeals. Those that do report the number misdemeanor appeals filed in appellate courts do not report whether it is the defense or the prosecution who appeals, or provide disposition information separately for misdemeanor appeals. ${ }^{56}$ Even the federal courts do not collect information about which criminal appeals filed in the federal courts of appeals are from misdemeanor judgments. 57

Prior scholarship addressing criminal appeals, too, has not discussed misdemeanor appeals separately, ${ }^{58}$ with three exceptions. One study reported

55 See Nat'l Ctr. for State Courts \& Conference of State Court Adm'rs, CT. STAT. PROJECT, http://www.courtstatistics.org/ (last visited Jan. 1, 2019) [https://perma.cc/CJ5Q-AVEB]. Upon request, we were provided aggregate data on misdemeanor appeals that were collected (but not reported) by the CSP. See Nat'l Ctr. for State Courts \& Conference of State Court Adm'rs, State Court Guide to Statistical Reporting, Cт. STAт. ProjeCT 46, http://www.courtstatistics.org/ /media/Microsites/Files/CSP/State\%20Court\%20Guide\%20to \%20Statistical\%20Reporting\%20v\%202point1point2.ashx (last updated Mar. 20, 2017) [https://perma.cc/PAA8-6X36]. Data were available for only a small number of states and did not indicate how many of the misdemeanor appeals were interlocutory or brought by the state rather than the defendant. The six-to-eight states reporting disposition information for 2015-16 reported reversal rates under 4 percent, much lower than the 8.3 percent and 14.8 percent rates (for courts of last resort and intermediate appellate courts, respectively) reported from the NCSC Appeals Study, which used a random nationwide sample of direct appeals only. See NCSC APPEALS STUDY, supra note 18, at 4 tbl.1, 5 tbl.2. The average rate of merits review by courts of last resort and intermediate appellate courts, combined, during the years 2014-16, from the five to ten states reporting this information, ranged from 58-70 percent, not far off the rates in the NCSC Appeals Study, which examined direct appeals only (37.9 percent for courts of last resort; 87.8 percent for intermediate appellate courts). As reporting practices improve, the CSP should eventually become an ongoing source of additional information about misdemeanor-case processing.

${ }^{56}$ See, e.g., Alabama Unified Judicial System, Fiscal Year 2017 Annual Report and Statistics 25-26 (reporting separately number of appeals filed from "municipal convictions" and number of appeals filed from "other convictions," but not providing information about disposition or whether any were filed by state), http://www.alacourt.gov/Annual\%20Reports/2017AOCAnnualReport.pdf.

57 The FJC Codebook for the integrated appellate database does not include a variable that would distinguish felony from misdemeanor appeals, hence the only reliable way to determine which criminal appeals are misdemeanors versus felonies is to collect original data from a sufficiently large sample of cases. The information on appeals collected by the U.S. Sentencing Commission also sheds little light on misdemeanor appeals. See King \& Heise, Appeals by the Prosecution, supra note 18, at 486-87 (discussing limitations of Commission's data); see also MARK Motivans, U.S. DeP'T OF Justice, Bureau OF Justice Statistics, Federal JUstice STATistics, 2013 - STATistical TABLES 26-28 (2017), https://www.bjs.gov/content/pub/pdf/fjs13st.pdf [https://perma.cc/3L6Q-9BHW] (discussing federal criminal appeals data but not addressing misdemeanor and felony appeals separately).

58 A leading study of criminal appeals, for example, did not discuss misdemeanors separately. See Joy A. Chapper \& ROger A. HANson, NAT'L CTR. For STATE CourTs, UNDERSTANDING REVERSIBLE ERROR IN CRIMINAL APPEALS (1989), 
that, of almost one thousand interlocutory, postconviction, and direct appeals filed in one Tennessee appellate court during the mid-1990s, 13 percent of those appeals receiving relief on appeal were misdemeanors. 59 A study of all decisions from the Iowa Court of Appeals in criminal cases from 2012 to 2013 in which the defendant was represented by counsel found that less than 4 percent involved the lowest-level misdemeanors, that about half the criminal appeals handled by retained counsel were misdemeanors, and that one in four criminal appeals were handled by publicly appointed counsel. ${ }^{60}$ Finally, our own recent study of prosecutor appeals ${ }^{61}$ included seventeen misdemeanors among the 154 prosecutor appeals from the nationwide random sample of direct criminal appeals in the NCSC Appeals Study. We found, contrary to our expectations, that the likelihood a prosecutor would win an appeal was unrelated to whether it was a misdemeanor or a felony. ${ }^{62}$

This Article goes far beyond the skeletal and incomplete information summarized above and focuses on questions helpful to policymakers, practitioners, judges, and scholars interested in misdemeanors and judicial review generally. In addition to the new information about two-tier trial court appeals and appeal-to-conviction ratios presented above, we exploit data from the NCSC Appeals Study to provide the first detailed description of

https://cdm16501.contentdm.oclc.org/digital/collection/criminal/id/1 [https://perma.cc/UZ6DGMUX]. Also not separating misdemeanors is the study of state high court decisions by Kagan, Brace, and Hall. See Project Overview, St. SuP. Ct. DATA Project, http://www.ruf.rice.edu/ pbrace/statecourt/ (last visited Jan. 2, 2019)

[https://perma.cc/V9AJ-6KXQ]. Other studies similarly fail to separate misdemeanors from felonies. See DAVID T. WASSERMAn, A Sword For THE ConviCTED: REPRESENTING INDIGENT DEFENDANTS ON APPEAL 87-109 (1990) (investigating criminal appeals in the New York State Appellate Division and the effects of defense representation); Thomas Y. Davies, Affirmed: A Study of Criminal Appeals and Decision-Making Norms in a California Court of Appeal, 1982 AM. B. Found. RES. J. 543; Theodore Eisenberg \& Geoffrey P. Miller, Reversal, Dissent, and Variability in State Supreme Courts: The Centrality of Jurisdictional Source, 89 B.U. L. REV. 1451 (2009); Note, Courting Reversal: The Supervisory Role of State Supreme Courts, 87 YALE L.J. 1191 (1978) (evaluating how state supreme courts supervise lower state courts); Project, The Effect of Court Structure on State Supreme Court Opinions: A Re-Examination, 33 STAN. L. REV. 951, 957 tbl.1 (1981).

59 Daniel J. Foley, The Tennessee Court of Criminal Appeals: A Study and Analysis, 66 TENN. L. REV. 427, 431, 454 tbl.6 (1999) (not reporting what percentage of criminal appeals filed were misdemeanors or what proportion of misdemeanors filed received relief).

${ }^{60}$ Buller, supra note 51, at 246 tbl.10, 247 tbl.15 (showing that 54 percent of appeals handled by retained counsel were misdemeanors and 46 percent were felonies); see also id. at 247 tbl.16, 248 tbls. $17 \& 18$ (showing that, among 275 misdemeanor appeals with represented appellants, only nine were "simple"—as opposed to "serious" or "aggravated"misdemeanors).

${ }^{61}$ King \& Heise, Appeals by the Prosecution, supra note 18, at 499.

$62 \mathrm{Id}$. at 508 ("Perhaps prosecutors were particularly selective when appealing in misdemeanor cases, choosing to devote appellate resources to these relatively minor cases only when a court's ruling was especially egregious."). 
misdemeanor cases that reach state appellate courts; compare misdemeanor appeals with misdemeanor cases in state trial courts to explore if and how the case mix changes on appeal; report descriptive information as well as the results of a detailed statistical analysis examining which of many features are significantly associated with a greater likelihood of success; and compare misdemeanor appeals with felony appeals.

\section{Research Questions}

We investigate three broad research questions: First, which misdemeanor cases reach appellate courts (and which do not)? Second, for the cases that are reviewed, what factors correspond with a higher likelihood of success? And third, do misdemeanor appeals systematically differ from felony appeals? These questions, and our hypotheses about possible answers given available data, are presented in more detail below.

\section{A. Do appellate courts see the same misdemeanor cases that trial courts} do?

With such a small percentage of the misdemeanor cases decided by trial courts even reaching appellate courts, it seems plausible that certain segments of the misdemeanor caseload in state trial courts might so rarely reach appellate courts that judicial review could not correct error or develop law unique to those types of cases. ${ }^{63}$ If there are entire categories of misdemeanor cases with little to no judicial oversight, identifying such a gap could be helpful for policy makers. Although very little information about misdemeanor cases at the trial court level exists to investigate this question, we were able to obtain some information about the mix of crime types from 16 states, ${ }^{64}$ allowing a limited comparison of trial and appellate case mix by crime type.

Crime type can serve as a rough proxy for sentence severity, information which is not available for either trial-level or appellate cases. ${ }^{65}$ As noted above in Part I, there are several reasons to expect that, on average nationwide, the misdemeanor cases that reach appellate courts include a lower percentage of less-serious misdemeanor cases than the proportion of less-serious cases handled by trial courts, and a higher percentage of the most

63 This concern has been raised repeatedly about the use of appeal waivers in plea agreements. See, e.g., Nancy J. King \& Michael E. O’Neill, Appeal Waivers and the Future of Sentencing Policy, 55 DuKE L.J. 209, 252-54 (2005). Although some degree of error correction could materialize on appeal to another trial court in two-tier systems, this Article focuses on the work and influence of appellate courts.

${ }^{64}$ See infra text accompanying notes 114-115.

65 On the lack of information on misdemeanor sentences, see supra notes $44-45$ and accompanying text. 
serious misdemeanors. Unlike many other misdemeanors, DUI offenses carry a mandatory minimum jail sentence in a significant number of states. ${ }^{66}$ As a result, we expected that DUI cases may produce, on average, more serious sentences than other misdemeanors and be overrepresented on appeal. Assault and other violent-crime cases may also carry more serious sentences than other types of misdemeanors and be overrepresented on appeal for that reason. ${ }^{67}$ At the other end of the spectrum, non-DUI driving or traffic offenses, in many jurisdictions the largest category of misdemeanor filings, ${ }^{68}$ are likely to be treated as less serious than other misdemeanors and underrepresented on appeal. These driving-related crimes include failing to report or leaving the scene of an accident; moving violations such as speeding, driving the wrong way, or reckless driving; and driving without a valid license, tag, or insurance.

We note here three other related hypotheses abandoned because of data constraints-hypotheses that might be examined later as better information develops. First, although we expected that the set of misdemeanor appeals that actually reached appellate courts would include many more first-level appeal cases than cases where the defendant had prior access to review by a felony trial court, the information needed to test this was not available for too many of the appeals in the sample. Nor were we able to confirm whether a disproportionate number of appeals had gone to trial, as is the case with felonies, because we could not reliably identify in our appeals data which appeals had followed a trial. ${ }^{69}$ Finally, although the CSP has started to collect

${ }^{66} 1$ LAFAVE ET AL., supra note $1, \S 1.11(\mathrm{c}-1)$ (4th ed. Supp. 2017-2018) (explaining that the DUI offense "carries a mandatory minimum jail sentence in a significant group of states," that several states that track misdemeanor dispositions track DUI offenses separately, and that "[t]hose disposition tables establish a pattern as to outcomes and modes of disposition indicating that the prosecution, defense, and court all addressed these traffic charges as serious crimes rather than as charges akin to infractions").

${ }^{67}$ Given the scholarly commentary that collateral consequences as well as the direct sentence may shape the defendant's perception of the seriousness of the offense, we thought DUI and violent offenses would be more likely than other categories to trigger those problems. As Professor Jenny Roberts notes, "Perhaps the greatest incentive to seek review of a misdemeanor conviction is the realization, after the case has ended, that a seemingly low-level misdemeanor conviction can lead to permanent, severe collateral consequences." Roberts, supra note 11, at 812 (citing Jain, supra note 3, at 958); see supra text accompanying notes 5-8; see also NATAPOFF, supra note 1, at 48-49 (noting several ways in which DUI and domestic violence charges are more "serious" than other misdemeanors).

681 LAFAVE ET AL., supra note 1, § 1.11(c-1), at 112-13 (4th ed. Supp. 2017-2018); see also NATAPOFF, supra note 1 , at 50 (addressing cases of driving with a suspended license, in particular, and noting that these cases alone make up 30-60 percent of some local dockets).

69 See supra text accompanying notes 52-53 for reasons that appeal rates are higher for defendants convicted at trial as compared to by guilty plea. Claim information in some cases and coding notes on relief ordered for many of the successful appeals did allow determination of whether the case had gone to trial, see infra note 119, but this information was not available for most cases. 
information on representation in misdemeanor cases at the trial level, that information could not be released. Had we gained access, we would have investigated whether the percentage of appellants without counsel70 is smaller than the percentage of misdemeanor defendants convicted in trial courts without counsel. ${ }^{71}$ If so, that would suggest that appellate oversight of issues that arise in pro se cases is even scarcer than oversight of counseled cases. ${ }^{72}$

\section{B. Which misdemeanor appeals succeed?}

We examined why some misdemeanor appeals failed and others succeeded by determining what features were associated with a greater likelihood of success. We investigated both whether an appeal was reviewed on the merits and whether relief was granted, ${ }^{73}$ for both appeals of right and appeals by permission. Based in part on our earlier work with the NCSC Appeals Study, we expected that three general categories of factors tracked by the dataset might correspond with a higher rate of merits review and ultimate success: state- and court-specific factors; the type of crime and type of claim raised; and advocacy-related factors. ${ }^{74}$ Presented below are our hypotheses about the relationships between each of these factors and merits review or success.

\footnotetext{
70 See discussion infra Section IV.C.2 (comparing percentage of misdemeanor appellants without counsel to percentage felony appellants without counsel, by crime type).

${ }^{71}$ See supra notes 46-481 and accompanying text (discussing reasons that misdemeanor defendants lack counsel).

72 For another hypothesis about misdemeanor appeals our data cannot test, consider the claim Justice Brennan made nearly fifty years ago when he warned that restrictions on misdemeanor appeals could corrode public support for courts generally. He wrote, for a unanimous Court, "Justice, if it can be measured, must be measured by the experience the average citizen has with the police and the lower courts.' Arbitrary denial of appellate review of proceedings of the State's lowest trial courts may save the State some dollars and cents, but only at the substantial risk of generating frustration and hostility toward its courts among the most numerous consumers of justice." Mayer v. City of Chicago, 404 U.S. 189, 197-98 (1971) (alteration in original) (footnote omitted) (quoting Patrick V. Murphy, The Role of the Police in Our Modern Society, 26 REC. Ass'N B. CITY N.Y. 292, 293 (1971), and holding that an indigent convicted of a misdemeanor and punished by fine is entitled to transcript for appeal).

${ }^{73} \mathrm{~A}$ third stage is required for success in some cases: harmless error review. The data do include variables about harmless error findings, but only for those appeals that produced a reasoned decision of the court. See King \& Heise, Appeals by the Prosecution, supra note 18, at 514 fig. 8 .

${ }^{74}$ Recent scholarship about misdemeanor prosecutions has documented racial disparity in misdemeanor cases, particularly in policing and pretrial detention, see Kohler-Hausmann, supra note 1313, at 635, 690; NATAPOFF, supra note 1, at 152-170. However, we were unable to examine whether success rates correlate with race or ethnicity, or any other demographic variable, as our data lack such information.
} 


\section{State and Court Specific Factors}

We predicted that, as compared to mandatory appeals, when appellate review requires permission from the court, the appellant is less likely to obtain review on the merits and thus less likely to win. ${ }^{75}$ We were also curious to find out if misdemeanor appeals that were filed in state courts of last resort were less likely to win than appeals in intermediate courts, even controlling for whether the review is discretionary, as we found with prosecutor appeals. ${ }^{76}$

An appellant's prospects for success might also be associated with whether the appeal reviewed the record for the first time or instead reviewed an appellate decision that itself had reviewed the record. Appellate courts may provide greater deference to trial court fact finding and exercises of discretion than they provide to decisions of another appellate court, for example. Alternatively, they could apply closer scrutiny to a trial court's decision than they would to a reviewing court's second look at the issue. ${ }^{77}$

Because busier courts have less time and fewer resources to spend on resolving their cases, and because it takes much longer to reverse a decision than to affirm one, we expected, as some prior research has found, that the busier courts overturn fewer decisions. ${ }^{78}$ We did not find any significant relationship between workload and appellate success in our study of felony appeals, so we doubted it would impact the even smaller group of misdemeanor appeals. To find out, we included a variable for workload in our analysis.

Finally, we were interested in learning if elected appellate judges were less likely than appointed judges to side with criminal defendants, ${ }^{79}$ even though that hypothesis was not supported by either our study of felony

\footnotetext{
75 We found this pattern in felony appeals. Heise, King \& Heise, State Criminal Appeals, supra note 18, at 1952-53 (finding 2.8 percent success rate for defendants who filed discretionary appeals in courts of last resort, compared to 14.9 percent success rate for first appeals of right). In our study of prosecutor appeals, we also found a slightly higher rate of success for mandatory appeals than for discretionary appeals. King \& Heise, Appeals by the Prosecution, supra note 18, at 506. In our regression analysis, however, once other factors were taken into account, whether the appeal was discretionary or mandatory made no significant difference to a prosecutor's likelihood of success on appeal. Id. at 507.

${ }^{76}$ King \& Heise, Appeals by the Prosecution, supra note 18, at 506.

77 See id. at 508 (finding high courts were less, not more, likely to reverse a decision from an intermediate court than from a trial court).

78 See Bert I. Huang, Lightened Scrutiny, 124 HARV. L. REV. 1109 (2011) (finding fewer reversals associated with caseload increases in federal courts).

79 See generally Michael S. Kang \& Joanna M. Shepherd, Judging Judicial Elections, 114 Mich. L. ReV. 929 (2016) (reviewing MELinda Gann Hall, ATTACKInG JudGEs: How CAMPAign AdVERTising INFLuences State SupREMe CourT Elections (2015)) (presenting study findings showing that judicial decisions become more hostile to criminal defendants as attack advertising in judicial elections increases).
} 
appeals by defendants ${ }^{80}$ or our study of prosecutor appeals. ${ }^{81}$ We decided to investigate this factor anyway in misdemeanor appeals, because of the possibility that those misdemeanor cases that make it as far as an appellate court might be cases in which the electorate or the judiciary is particularly interested.

2. Type of Crime and Type of Claim Raised.

The likelihood that a reviewing court will decide to review or overturn a conviction or sentence may, like a defendant's ability and willingness to file an appeal, vary with the type and seriousness of the crime. A court with the discretion to deny review may allocate its limited error-correcting resources to cases with higher stakes or to the supervision of certain types of crimes. For example, in our study of felony appeals by state defendants, we found that, among discretionary appeals to courts of last resort, drug-trafficking cases were significantly associated with a higher likelihood of being granted review than other types of cases. ${ }^{82}$ Crime type may also relate to outcome if error rates, or a court's concern about correcting error, differ by crime. Among appeals by state defendants in felony cases that high courts agreed to review, for example, sex offenses were significantly associated with a greater likelihood of relief. ${ }^{83}$ At least one past study found that defense appeals in violent-crime cases were less likely to succeed, ${ }^{84}$ which would be expected if a larger percentage of meritless appeals were filed in these cases with the longest sentences or if media coverage or the presence of victims makes granting relief to defendants convicted of violent crimes more difficult than granting relief to defendants in other cases. We hoped to learn what crimespecific relationships emerged in the misdemeanor appeals context, although we suspected that the reasons for variation may differ from felony cases. For example, reversal rates for appeals of felony sex crimes might be higher because of difficult evidentiary issues, while higher reversal rates for appeals

80 See Heise, King \& Heise, State Criminal Appeals, supra note 18, at 1968.

${ }^{81}$ See King \& Heise, Appeals by the Prosecution, supra note 18, at 515.

82 Heise, King \& Heise, State Criminal Appeals, supra note 18, at 1968.

${ }^{83} \mathrm{Id}$. at 1963 . In our analysis of state prosecutor appeals, where we were able to control for only three crime categories-violence; drug-trafficking, DUI, and weapons; and everything else-we found no significant relationships with success. King \& Heise, Appeals by the Prosecution, supra note 18, at 512 fig.3. A much earlier study of state high courts found that, of all criminal appeals, sex offenses and public-order offenses had the highest reversal rates. Note, supra note 58, at 1210 (characterizing such offenses as "crimes against public order or morality" and offering as explanation that these prosecutions are often emotionally charged and "such laws are enforced unevenly," creating divisions in lower courts).

${ }^{84}$ ChAPPER \& HANson, supra note 58, at 36; see Heise, King \& Heise, State Criminal Appeals, supra note 18, at 1949, 1968 (citing Chapper and Hanson's study and testing likelihood of felony appeals' success by type of offense). 
of misdemeanor sex crimes might be related to judicial concern about requiring sex-offender registration for very minor offenses.

The likelihood of success may also vary with the type of claim raised by misdemeanor appellants. In felony appeals, defendants who raised claims involving certain trial issues (e.g., competency, interpreters, mistrial, joinder) were significantly more likely to succeed than defendants who raised other issues. ${ }^{85}$ In misdemeanor appeals, we explored five specific types of claims. First, we expected a sizeable portion of cases securing relief would be cases in which the defendant was convicted after trial but claimed innocence on appeal; that is, insufficient evidence to convict. By going to trial, these particular defendants already demonstrated an extraordinary determination to fight, which may carry over to the appellate process. And despite the difficulty of overturning credibility determinations of juries and judges that convict, ${ }^{86}$ some of these cases will lack sufficient basis if the investigation and adjudication of these cases is as slapdash and inaccurate as critics claim. ${ }^{87}$ Finally, to the extent that insufficient evidence claims are raised by many of those contesting trial convictions, the claim might stand in as a proxy for a key piece of information missing from our data-which appeals followed trial rather than guilty plea, allowing some insight about whether appeals after trial are more successful than appeals after guilty plea. ${ }^{88}$

Second, and also linked to poor policing and prosecutorial screening, we wanted to find out if suppression claims fared better or worse than other claims. In felony appeals, the presence of a suppression claim significantly increased the likelihood of merits review by state high courts but made no difference when it came to success among granted cases. If compliance with the law is looser in misdemeanor cases generally, and if error rates are higher, appellate courts might reverse cases raising such claims at a higher rate than other claims.

Third, as we found with felony appeals of right by state defendants, ${ }^{89}$ we expected that sentencing challenges when raised in misdemeanor appeals

\footnotetext{
85 See Heise, King \& Heise, State Criminal Appeals, supra note 18, at 1960-61 (reporting results for first appeals of right); id. at 1962-63 (reporting results for discretionary appeals to courts of last resort).

${ }^{86}$ See Roberts, supra note 11, at 813 ("Appellate courts defer to the trial court's credibility judgments making appeals . . . in these common misdemeanor scenarios quite difficult.").

87 See, e.g., BorUCHOWITZ, BRINK \& DIMINO, supra note 49, at 14 ("[T] he operation of misdemeanor courts in this country is grossly inadequate and frequently unjust."); NATAPOFF, supra note 1, at 55-112.

88 See Samuel R. Gross, Errors in Misdemeanor Adjudication, 98 B.U. L. REV. 999, 1011 (2018) (arguing that going to trial helps secure an exoneration and finding, in study of eighteen misdemeanor exonerees, that fifteen went to trial, eleven of which had convictions reversed on appeal).

89 See Heise, King \& Heise, State Criminal Appeals, supra note 18, at 1960-61 (reporting results for first appeals of right); see also id. at 1965-66 (discussing findings). Although
} 
might be particularly likely to succeed compared to appeals challenging only conviction, since correcting sentencing errors may be easier and cheaper for both appellate and trial court than relitigating guilt.

Fourth, our data identified cases raising issues of statutory interpretation. We thought that because of the statewide impact of rulings on statutory interpretation questions, such issues would be more likely than case-specific errors to receive merits review. Also, questions of statutory interpretation raised on appeal are likely to be unsettled and could succeed at a higher rate than other, more settled issues.

Finally, we tracked constitutional challenges to statutes, for similar reasons. 90 Not only do these have system-wide impact, but defendants are more likely to raise them, as they are not waived by plea. ${ }^{91}$ Compared to other claims, however, fewer of these challenges may have merit if defendants raise them routinely for preservation, in anticipation of future doctrinal change or for other reasons, suggesting that fewer of them will be granted review or receive relief.

\section{Advocacy-related variables.}

We expected that prosecutor appellants would be more likely to win than defendants who appeal. ${ }^{92}$ In felony cases, the rate of merits review and success when prosecutors appeal is much higher than the rate of merits review and success when defendants appeal. ${ }^{93}$ The probable explanations for this should apply to felonies and misdemeanors alike: compared to defense appeals, challenges to prodefendant rulings subject to appeal by the prosecution may involve error that is easier for courts to identify and claims less likely to be forfeited or subjected to harmless error. More importantly, prosecutor appeals are often coordinated by a statewide office, carefully

defendants' first appeals of right from the sentence saw a higher likelihood of success than conviction appeals, it was conviction-only appeals—not sentence appeals-that proved significantly related to the success of appeals by defendants to courts of last resort. $I d$. at 1962-63, 1966.

${ }^{90}$ One experienced staff attorney has suggested that constitutional issues are an important category of misdemeanor appeals. See Stan Keillor, Should Minnesota Recognize a State Constitutional Right to a Criminal Appeal?, 36 HAMLine L. REv. 399, 425 (2013):

Removing the right to appeal misdemeanor convictions or convictions based on guilty pleas would shield from appellate review, for example, many First Amendment issues that arise in disorderly conduct, obstructing legal process, and indecent exposure cases, as well as the due process and Sixth Amendment issues posed by guilty plea-based convictions.

${ }^{91}$ See Class v. United States, 138 S. Ct. 798, 803 (2018).

92 See King \& Heise, Appeals by the Prosecution, supra note 18, at 485 (collecting authority). 93 Id. at 509-14. 
screened and selected for success, and litigated by experienced appellate counsel. 94

Type of legal representation, too, may matter. If retained counsel enjoy more resources or expertise than publicly appointed counsel, or if appellants who must finance their own appeals have more incentive than those with publicly appointed counsel to avoid appealing losing claims, then it follows that the presence of retained counsel would correspond with greater success. ${ }^{95}$ We did not find support for this hypothesis in our prior studies of felony appeals and prosecution appeals. ${ }^{96}$ However, the greater proportion of retained counsel that we anticipated among misdemeanor appeals ${ }^{97}$ could suggest a different result. Alternatively, experienced publicly funded counsel may outperform retained counsel, who represent misdemeanor appellants less frequently. ${ }^{98}$ When publicly appointed counsel filed an Anders-type statement that no meritorious issues existed for appeal, ${ }^{99}$ we expected that appellants would be less likely to succeed than in cases without such concessions. ${ }^{100}$

We also expected that, like felony appellants, misdemeanor appellants representing themselves would fare worse than those with representation. ${ }^{101}$ This would be consistent with the Court's rationale for interpreting the Constitution to guarantee a right to appointed counsel on appeal for at least some misdemeanors ${ }^{102}$ but inconsistent with some evidence that

${ }_{94} I d$. at 485.

${ }^{95}$ In his study of Iowa appeals, Buller, supra note 51, at 210-11, 220, found that privately retained counsel obtained favorable outcomes in 22 percent of their cases, compared to 19 percent for appellate defenders, but defenders won dismissal or acquittal of at least one count of conviction in 3.7 percent of cases, compared to retained counsel's 2.4 percent. For sentencing issues, defenders succeeded in 9.5 percent of cases, compared to retained attorneys' 7.3 percent. Court-appointed counsel were consistently worse than defenders and retained counsel in all categories. See also WASSERMAN, supra note 58, at 97 (appellants represented by the Criminal Appeals Bureau of the Legal Aid Society obtained favorable actions more often than assigned counsel, but less often than retained counsel).

96 See Heise, King \& Heise, State Criminal Appeals, supra note 18, at 1960-61 (finding that presence of private attorney had the same favorable association with outcome as did presence of public attorney, when each was compared to appeals with all other forms of representation); King \& Heise, Appeals by the Prosecution, supra note 18, at 516 (finding that representation by retained attorney had no significant association with variation in likelihood of relief in either prosecution or defense appeals).

97 See supra note 60 and accompanying text.

98 For example, we found that in federal appeals by the government, federal defenders were associated with more success for their clients than were panel attorneys or retained counsel. See King \& Heise, Appeals by the Prosecution, supra note 18, at 521.

99. On Anders rules generally, see 3 LAFAVE ET AL., supra note 1, § 11.2(c).

100 See Heise, King \& Heise, State Criminal Appeals, supra note 18, at 1960-61 (finding presence of Anders brief correlated with lower likelihood of success).

101 See id. (finding pro se defense correlated with lower likelihood of success).

102 See Argersinger v. Hamlin, 407 U.S. 25, 32 (1972) ("Both Powell and Gideon involved felonies. But their rationale has relevance to any criminal trial, where an accused is 
misdemeanor defendants representing themselves in federal trial court fared no worse than those who had counsel. 103

Based on prior studies, we expected that the presence of oral argument and the filing of a reply brief by the appellant would be related to a higher rate of success, ${ }^{104}$ as each provides an additional opportunity to persuade and may indicate generally more zealous advocacy. Granting oral argument could also signal the court's perception of the appeal's importance or merit. We recognized that there may be reverse causal relationships here-for example, if courts authorize oral argument or reply only after agreeing to review the appeal, or if the decision to issue a full opinion is made after the decision to grant relief-so we designed our analyses with this in mind.

\section{Comparing Misdemeanor and Felony Appeals}

In exploring differences between misdemeanor and felony appeals, we expected that misdemeanor appeals would include fewer indigents with publicly funded counsel and a correspondingly greater proportion of defendants with either retained counsel or no counsel at all. ${ }^{105}$

As for win rates, predictions conflicted. Some differences suggest that misdemeanor appeals would be less successful than felony appeals. The defenders appointed in these cases may be may be less experienced, ${ }^{106}$ and with lower penalties at stake, reviewing courts may take these cases less seriously than felonies. ${ }^{107}$ Also, if, compared to felony appellants, a smaller

deprived of his liberty.”); see also Gideon v. Wainwright, 372 U.S. 335, 344 (1963) (noting prosecution's resource and expertise advantages relative to defendants); Powell v. Alabama, 287 U.S. 45, 68-69 (1932) (discussing the difficulty of "[e]ven the intelligent and educated layman" to prepare an effective defense).

103 See Erica J. Hashimoto, The Price of Misdemeanor Representation, 49 WM. \& MARY L. REV. 461, 466, 490-91 (2007) (reporting, from aggregate data on federal misdemeanor cases in 2000-05, that pro se misdemeanor defendants had better outcomes than represented misdemeanor defendants in both determinations of guilt and sentencing).

104 See King \& Heise, Appeals by the Prosecution, supra note 18, at 516, 530 (noting for appeals in state court, oral argument increases the chances of a favorable outcome for the appellant, but that in federal appeals by prosecutors, oral argument is associated with a lower likelihood of success); see also Foley, supra note 59, at 444 (finding, in study of Tennessee Court of Criminal Appeals decisions in defense appeals, that the state prevailed in 83 percent of cases submitted solely in briefs but only in 61 percent of cases with oral argument).

105 Buller reported that in Iowa in 2012-13, a larger proportion of appellants in misdemeanor direct appeals had retained counsel than did felony appellants (he did not track pro se appellants). Buller, supra note 51, at 254 tbls. $31 \& 33$.

${ }^{106}$ Irene Oritseweyinmi Joe, Rethinking Misdemeanor Neglect, 64 UCLA L. REV. 738, 750 (2017) ("Some public defender agencies . . . allocate attorney experience in a manner such that it is disproportionately dedicated to clients charged with felony offenses.").

107 See, e.g., John T. Wold \& Greg A. Caldeira, Perceptions of "Routine" Decision-Making in Five California Courts of Appeal, 13 POLITY 334, 344 (1980) (interviewing California court of 
proportion of misdemeanor appellants have appellate defenders as lawyers, and defenders generally secure better results for their clients than retained or appointed counsel, 108 then as a group, misdemeanor defendants may have less effective advocacy than felony defendants.

Other factors, however, might raise the likelihood of success compared to felony appeals. A larger proportion of retained counsel among misdemeanor appellants may translate to an overall pool of appeals more carefully selected for success than felony appeals. ${ }^{109}$ It is also possible that a larger percentage of the misdemeanor convictions appealed, or certain categories of misdemeanors appealed, compared to felony convictions appealed, are appellants' very first criminal convictions. For a first offender, the ruling on appeal is the difference between having a clean record and having a criminal history; both appellants and courts could be particularly keen to correct error in such cases. ${ }^{110}$ While data limitations hampered our ability to investigate some of these hypotheses, we pursued those that we could.

appeal justices, one of whom described the monotony and boredom of dealing with routine cases, described as "these rotten little cases").

108 The appointment of the appellate defender is limited to felony appellants in some states. See, e.g., 725 ILl. CoMP. STAT. 5 / 121-13 (2018); ILL. SuP. CT. R. 607(a) (providing for court to appoint counsel on appeal only to defendant found guilty of a felony or Class A misdemeanor or sentenced to prison). In Michigan, the State Appellate Defender Office services only felony defendants. See State Appellate Def. Office \& Mich. ApPellate ASSIGNED COUNSEL SYS., ANNUAL REPORT 6 (2017),

http://www.sado.org/content/commission/annual_report/11037_2017-Annual-Report.pdf [https://perma.cc/HT65-53KN] (stating as mission to "seek[ ] the best possible outcomes for indigent clients who appeal their felony convictions"). In New Hampshire, appellate defenders represent only felonies and the most serious misdemeanors. See Christopher M. Johnson, The New Hampshire Appellate Defender Program: An Apprenticeship Clinic, 75 Miss. L.J. 825, 830 (2006).

109 See Heise, King \& Heise, State Criminal Appeals, supra note 18, at 1951 (hypothesizing that "retained counsel would perform better than publicly funded counsel, in part because losing cases are less likely to be pursued when the defendant is paying"). We found that, among prosecutor appeals, the likelihood of success for felonies and misdemeanors did not differ significantly, which we speculated might be the result of greater selectivity by prosecutors in choosing only the most egregious misdemeanor rulings to appeal. King \& Heise, Appeals by the Prosecution, supra note 18, at 508.

${ }^{110}$ Because of the scanty available information on misdemeanor convictions and sentences, this hypothesis not realistically testable, although it is consistent with available data from three jurisdictions. See DiAL, KING \& WESOLOSKI, supra note 45, at 2-3, 33-34 (finding 29.0 percent of selected misdemeanor defendants and 27.7 percent of felony defendants were in lowest criminal history category); Dobbie, et al., supra note 14, at 212 Tbl. 1, App. Tbl. A-14 (reporting statistics from study of more than 400,000 criminal cases in Philadelphia and Miami that show that a greater percentage of misdemeanor defendants (55.8) compared to felony defendants (50.6)) had no prior conviction. 


\section{Data and Research Design}

\section{A. Data}

Our primary data source was drawn from a nationally representative probability sample of the decisions entered in 2010 in direct criminal appeals by every state appellate court with criminal jurisdiction. ${ }^{111}$ From an initial universe of 4,650 criminal appeals, we excluded appeals in felony and death penalty cases, then further excluded seven appeals from the Iowa Supreme Court that were not actually completed but instead transferred to the state's intermediate court; this left 403 misdemeanor appeals for our analyses.

\section{Outcome Measures}

We focused on two outcome measures: (1) "merits review," defined as whether the appeal was reviewed on its merits rather than terminated for a reason unrelated to the merits, and (2) "favorable decision," defined as whether an appeal's outcome involved anything other than an affirmance, dismissal, denial of review, or withdrawal. ${ }^{112}$ As Table 1 illustrates, among our 403 misdemeanor appeals, 260 (or 64.5 percent) were reviewed on the merits. The remaining 143 appeals were denied review by the appellate court, dismissed for a procedural problem unrelated to the merits, or withdrawn by the appellant. Among all 403 misdemeanor appeals, 11.2 percent succeeded. Of those reviewed on the merits, 17.3 percent succeeded.

\section{Table 1: Merits Review and Favorable Decision, by Appeal Type}

\begin{tabular}{lccc}
\hline & Merits review (\%) & $(\mathrm{N})$ & (total) \\
\cline { 2 - 4 } Discretionary, of all cases filed & 18.8 & 24 & 128 \\
Appeal of right, of all cases filed & 86.6 & 238 & 275 \\
& & & \\
& Favorable decision (\%) & $(\mathrm{N})$ & (total) \\
\cline { 2 - 4 } Appeal of right, of all cases filed & 13.1 & 36 & 275 \\
Discretionary, of all cases filed & 7.0 & 9 & 128 \\
Discretionary, of cases granted review & 37.5 & 9 & 24 \\
\hline
\end{tabular}

SourCE: Survey of State Court Criminal Appeals, 2010.

\footnotetext{
111 For a general description of the appeals data set, see U.S. DEP'T OF JUSTICE, BUREAU OF Justice Statistics, SuRvey of State Court CRiminal APPEALs, 2010: CoDEbook (July 5, 2016), https://www.icpsr.umich.edu/icpsrweb/NACJD/studies/36465\# [https://perma.cc/95NT-GPLJ]. The data for this study are from the main data set of NCSC APPEALS STUDY, supra note 18. For a table breaking down the misdemeanor sample by state, with success rates by states, see Appendix A Table 1.

112 In addition to full and partial reversals, remands and modifications to sentences were considered favorable outcomes for the appellant, as the data offer no reliable method to distinguish significant modifications or remands from less meaningful ones. This approach comports with prior empirical work examining appeals. See, e.g., CHAPPER \& HANsON, supra note 58, at 5; Theodore Eisenberg \& Michael Heise, Plaintiphobia in State Courts Redux? An Empirical Study of State Court Trials on Appeal, 12 J. EMPIRICAL LEGAL STUD. 100, 115 n.72 (2015).
} 


\section{Independent Variables}

Our other tables and models include the three groups of other factors that we thought, as previously discussed, might inform the likelihood of merits review or success: (1) state- and court-specific factors; (2) crime of conviction and claims raised on appeal; and (3) factors related to advocacy. ${ }^{113}$ Each of these independent variables is defined in Appendix A. Information about individual defendants, such as race, gender, age, or criminal history, was not available.

\section{B. $\quad$ Statistical Analyses}

In addition to descriptive information, our analyses report each variable's independent influence on (1) whether an appeal was reviewed on the merits and, conditioned on whether an appeal received a merits review, (2) whether the appellant succeeded on appeal. Our data set's structure and size allow us to specify selection regression models that better capture the inherent underlying two-stage structure of the criminal appellate process. Specifically, of the 403 misdemeanor appeals, 260 (or 64.5 percent) received merits review. Among the 143 appeals that did not receive merits review, none prevailed. Among the 260 appeals that did receive merits review, forty-five (or 17.3 percent) succeeded.

From a research design perspective, what is important is that merits review was a necessary, but itself an insufficient, condition for an appeal's success. This first stage (the decision about whether an appeal was heard on the merits) results in data censoring. We therefore assume that the subpool of 143 appeals that did not receive merits review systematically varied from the subpool of 260 appeals that did. Our Heckman selection model specifications permit us to explore an appeal's prospect for success conditioned on that appeal receiving a merits review and facilitates an empirical check on our assumption about whether the subpool of appeals that did not receive merits review systematically varied from those appeals that did receive merits review.

\section{Results and Discussion}

\section{A. Do appellate courts review every type of misdemeanor case that trial courts process?}

To examine the differences between appellate and trial level case mix (our first research question), we first present, in Table 2, descriptive information about the random sample of appeals examined for this study.

\footnotetext{
113 The variables were formulated to facilitate answers to the research questions as well as comparisons with our prior criminal appeals studies. See Heise, King \& Heise, State Criminal Appeals, supra note 18, at 1949-52; King \& Heise, Appeals by the Prosecution, supra note 18 , at $490-92$.
} 
King \& Heise 2-15 draft

TABle 2: Summary of VARIABles, as Percentage of SAMPle

\begin{tabular}{|c|c|c|}
\hline Independent variables: & $\begin{array}{l}(1) \\
N\end{array}$ & $\begin{array}{c}(2) \\
\%\end{array}$ \\
\hline Court of last resort & 198 & 49.1 \\
\hline Mandatory review appeal & 275 & 68.2 \\
\hline $1^{\text {st }}$ appellate review & 185 & 45.9 \\
\hline $2^{\text {nd }}$ appellate review & 26 & 6.5 \\
\hline (unknown layer appellate review) & 192 & 47.6 \\
\hline \multicolumn{3}{|l|}{ Appeal from: } \\
\hline Conviction (alone) & 239 & 59.3 \\
\hline Sentence (included) & 90 & 22.3 \\
\hline (unknown) & 74 & 18.4 \\
\hline \multicolumn{3}{|l|}{ Crime type: } \\
\hline Drug trafficking, weapons & 21 & 5.2 \\
\hline Violence (homic., robbery, assault) & 98 & 24.3 \\
\hline Sex crime & 10 & 2.5 \\
\hline DUI & 87 & 21.6 \\
\hline Drug-possession & 52 & 12.9 \\
\hline Other driving related & 31 & 7.7 \\
\hline Property & 34 & 8.4 \\
\hline Court order violation & 11 & 2.7 \\
\hline Other and unknown & 59 & 14.6 \\
\hline \multicolumn{3}{|l|}{ Claim included in brief: } \\
\hline Evidence suppression & 54 & 13.4 \\
\hline Insufficient evidence & 115 & 28.5 \\
\hline Sentence & 29 & 7.2 \\
\hline Statutory interpretation & 20 & 5.0 \\
\hline Statute constitutionality challenge & 10 & 2.5 \\
\hline Claims other than above & 62 & 15.4 \\
\hline (claim raised unknown) & 148 & 36.7 \\
\hline \multicolumn{3}{|l|}{ Court factors: } \\
\hline Elected judges & 212 & 52.6 \\
\hline PA state & 74 & 18.4 \\
\hline \multicolumn{3}{|l|}{ Process \& advocacy factors: } \\
\hline Prosecutor initiated appeal & 13 & 3.2 \\
\hline Anders/Wende & 17 & 4.2 \\
\hline Reply brief filed & 60 & 14.9 \\
\hline Oral argument held & 49 & 12.2 \\
\hline Full judicial opinion & 127 & 31.5 \\
\hline Private defense attorney & 69 & 17.1 \\
\hline Public defense attorney & 228 & 56.6 \\
\hline Pro se defendant & 23 & 5.7 \\
\hline (unknown representation) & 83 & 20.6 \\
\hline$N$ & 403 & \\
\hline
\end{tabular}

SouRCE: Survey of State Court Criminal Appeals, 2010.

As noted earlier, published information on trial court processing of misdemeanor cases includes virtually none of the details in Table 2. However, data obtained from the CSP do allow for an admittedly limited examination of how the crime-type mix in the pool of misdemeanor appeals differs from that in the pool of misdemeanor cases processed by trial courts. ${ }^{114}$ We compared

${ }^{114}$ Charge types in arrest data could serve as imperfect proxies for crime types in misdemeanor filings. See Thomas Cohen, Neal Kauder \& Brian Ostrom, A Renewed Interest in Low-Level Crime, 6 CASElOAd Highlights, Examining the Work of State CourTs No. 2, 5 (2000), https://cdm16501.contentdm.oclc.org/digital/collection/criminal/id/40 (stating 
the average crime-type percentages for misdemeanor cases decided by appellate courts nationwide in 2010 with cases filed in sixteen states' trial courts for various years 2012-16.115 The results, presented in Figure 1, suggest that, on average, (1) the percentage of appeals from DUI and violentcrime convictions exceeds the percentage of cases processed in trial courts for these crimes and (2) the percentage of appeals from non-DUI driving convictions is smaller than the proportion of such cases in trial courts.

\section{Figure 1. Crime Type, as Percentage of Misdemeanor Cases, Trial COURT FILINGS AND APPEALS COMPARED}

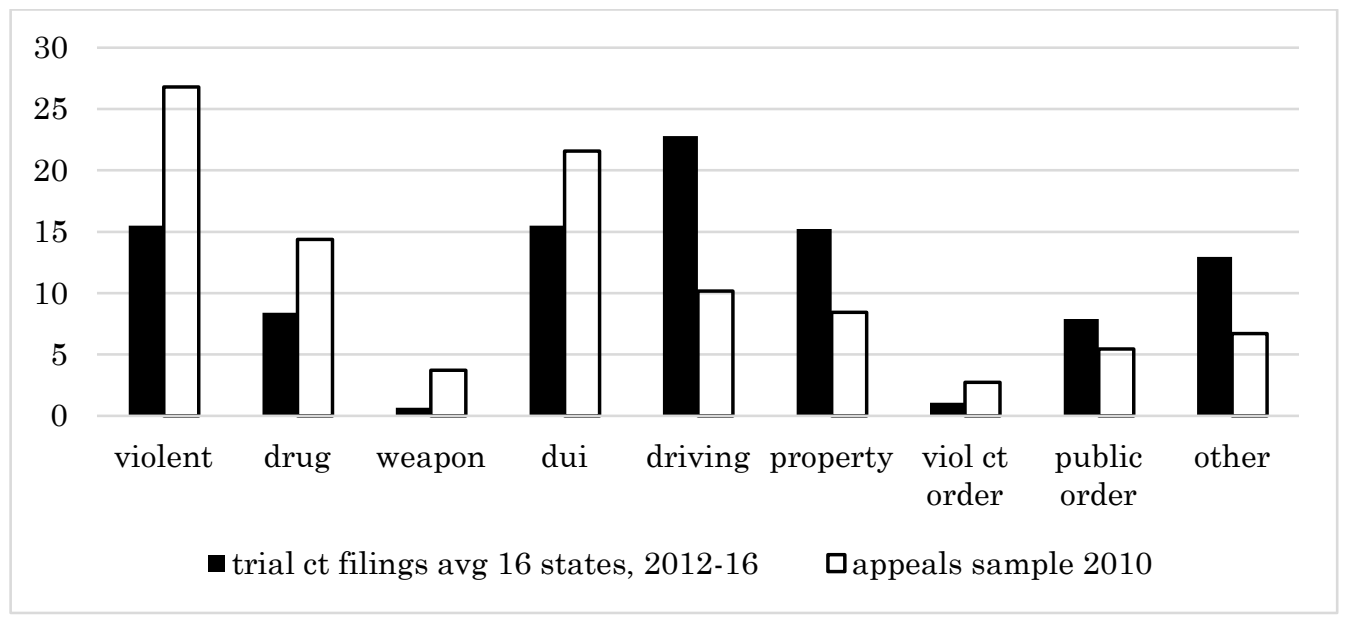

SourCE: Survey of State Court Criminal Appeals, 2010; Trial data from CSP by request.

that arrest and filing rates "generally track each other" and estimating misdemeanor filings based on Uniform Crime Reporting ("UCR") arrest data). But many misdemeanor cases begin with summonses, not arrests, and arrest data are not separated by misdemeanor or felony. So, evaluation must rely on available offense categories that are likely misdemeanors and may contain some felony charges. See Stevenson \& Mayson, supra note 1 , at 750 . Even with these problems, the most frequent categories of nontraffic crimes are fairly consistent. See id. at 758 fig. 12 (showing offenses with highest arrest rates are drug possession, theft, DUI, and assault). We also considered comparing caseload mix by using the National Incident-Based Reporting System ("NIBRS"), National Incident-Based Reporting System: Data Collection Guidelines, FED. BuREAU InVESTIGATION (Aug. 2000), https://ucr.fbi.gov/nibrs/nibrs_dcguide.pdf (showing categories of NIBRS offenses).

However, reporting for the NIBRS database is not yet as complete as the UCR's. See Fed. Bureau of Investigation, Methodology, Uniform CrIme RePORTING PROGRAM (2017), https://ucr.fbi.gov/nibrs/2016/resource-pages/methodology-2016_final_.pdf; Press Release, Fed. Bureau of Investigation, FBI Releases 2016 NIBRS Crime Statistics in Report and CDE, Promotes Transition of Agencies (Dec. 11, 2017), https://ucr.fbi.gov/nibrs/2016/resource-pages/nibrs-2016_summary.pdf ("Currently, the FBI does not estimate for agencies that do not submit NIBRS data.").

115 Data were limited-available from a total of sixteen states, with four states reporting only one year between 2012 and 2016, seven states reporting data for all five years, and the remaining five states having some amount of data in between. 
In addition, we also made a similar comparison for each of the two jurisdictions with the largest volume of appeals in our data: Pennsylvania and the District of Columbia.116 These particular jurisdictions also showed a greater percentage of violent-crime cases on appeal compared to the trial court. But unlike the other states, the District of Columbia and Pennsylvania experienced a lower percentage of DUI cases on appeal compared to trial courts, and a higher percentage of other driving cases on appeal compared to trial court.

Overall, judging from the limited information about trial courts available from about a third of the states, all basic crime categories appear to be represented among the misdemeanor cases that reach state appellate courts. There appears to be no category that escapes appellate review entirely, meaning no obvious blind spots for appellate courts, at least among general crime types when averaging states with available information together. But the mix of misdemeanor crimes in appellate courts differed from that experienced by trial courts. In most of the jurisdictions with available data, appellate judges review a greater percentage of misdemeanor cases that involve violent and DUI offenses than the percentage that trial judges handle, but a much-reduced proportion of the category of misdemeanor crime that inundates the nation's trial courts: traffic crime.

\section{B. Which cases succeed on appeal?}

This section examines which of the misdemeanor appeals in the nationwide sample succeeded and why. We begin with a look at the winning defense appeals in the national sample, then turn to descriptive statistical comparisons, and finally to more sophisticated analysis.

Coding in the NCSC Appeals Study includes more information for the appeals that succeeded than for those that failed, including the claim or claims that won and an explanation of what sort of relief was ordered.117 These additional data reveal at least two patterns consistent with expectations. Providing additional evidence that appellate review is more accessible and successful for those who contest guilt compared to those who pled guilty, ${ }^{118}$ at least 40 percent, and maybe more, of the successful misdemeanor appeals were from trials - a stark contrast to the small sliver of misdemeanor dispositions following trial rather than plea. ${ }^{119}$ Second, about 75 percent of

\footnotetext{
116 See Appendix A Table 1.

117 These text fields explained the effects of reversals, remands, and modifications.

118 See supra notes 52-53 and accompanying text (summarizing why guilty plea defendants have less access to appeal).

119 See supra note 23 and accompanying text. As noted earlier, no variable identified whether the judgment appealed was a trial or plea conviction, but in these cases, trials could be identified from the nature of the claim and the coders' notes.
} 
winning appeals secured relief from conviction, suggesting that when it comes to misdemeanors, appellate judges, like appellants, may be more concerned with errors underlying convictions than they are with sentencing. ${ }^{120}$

1. Descriptive findings regarding variation in win rates.

As predicted, in simple comparisons reported in Table $3,{ }^{121}$ several factors correspond with higher win rates: mandatory (versus discretionary) review; intermediate (versus last-resort) courts; appointed (versus elected) judges; first (versus second and unknown) layer of appellate review; sex-crime appeals (versus all other) crime types; prosecutor (versus defense) appellants; appeals that include oral argument, reply briefs, or full opinions (versus those that do not); and appeals raising claims challenging sentence, sufficient evidence, or statutory interpretation (versus appeals raising other claims). Non-DUI driving-related appeals also had a higher win rate than other crime types, which we did not predict.

\section{TABle 3: Summary of VARIABles, By Decision FAVORING APPELlant}

\begin{tabular}{|cc}
\hline $\begin{array}{c}(1) \\
\text { \% cases w/ variable } \\
\text { receiving decision } \\
\text { favoring appellant }\end{array}$ & $\begin{array}{c}\text { \% cases w/o variable } \\
\text { receiving decision } \\
\text { favoring appellant }\end{array}$ \\
\hline 7.6 & 14.6 \\
13.1 & 7.0 \\
14.6 & 8.3 \\
3.9 & 11.7 \\
8.9 & 13.3 \\
& \\
13.0 & 8.5 \\
14.4 & 10.2 \\
1.4 & 13.4 \\
& \\
9.5 & 11.3 \\
10.2 & 11.5 \\
40.0 & 10.4 \\
11.5 & 11.1 \\
5.8 & 12.0 \\
19.4 & 10.5 \\
\hline
\end{tabular}

\section{Independent Variables:}

Court of last resort $[\mathrm{n}=198]$

Mandatory review appeal $[n=275]$

$1^{\text {st }}$ appellate review $[\mathrm{n}=185]$

$2^{\text {nd }}$ appellate review $[\mathrm{n}=26]$

(unknown layer appellate review) [n=192]

Appeal from:

Conviction (alone) $[\mathrm{n}=239]$

Sentence (included) $[\mathrm{n}=90]$

(unknown) [n=74]

Crime type:

Drug trafficking, weapons $[\mathrm{n}=21]$

Violence (homic., robbery, assault) [n=98]

Sex crime $[n=10]$

DUI [n=87]

Drug possession $[\mathrm{n}=52]$

Other driving related $[\mathrm{n}=31]$

${ }^{120}$ For example: Of the six driving-related appeals that succeeded, five received relief from conviction, not sentence, including three finding insufficient evidence of guilt and another being remanded for a plausible claim of ineffective assistance of counsel. All four successful drug or weapons appeals won on a suppression issue. All four winning sex-offense appeals overturned convictions, three for trial error and one for competency. DUI cases were reversed for denial of self-representation, indictment problems, other evidence issues, as well as sentencing errors.

${ }^{121}$ A similar set of findings on success rates for misdemeanor appeals, but without the thirteen prosecutor appeals, and separated by whether the appeal was mandatory or discretionary, appears infra Table 4, columns 1 and 3. 


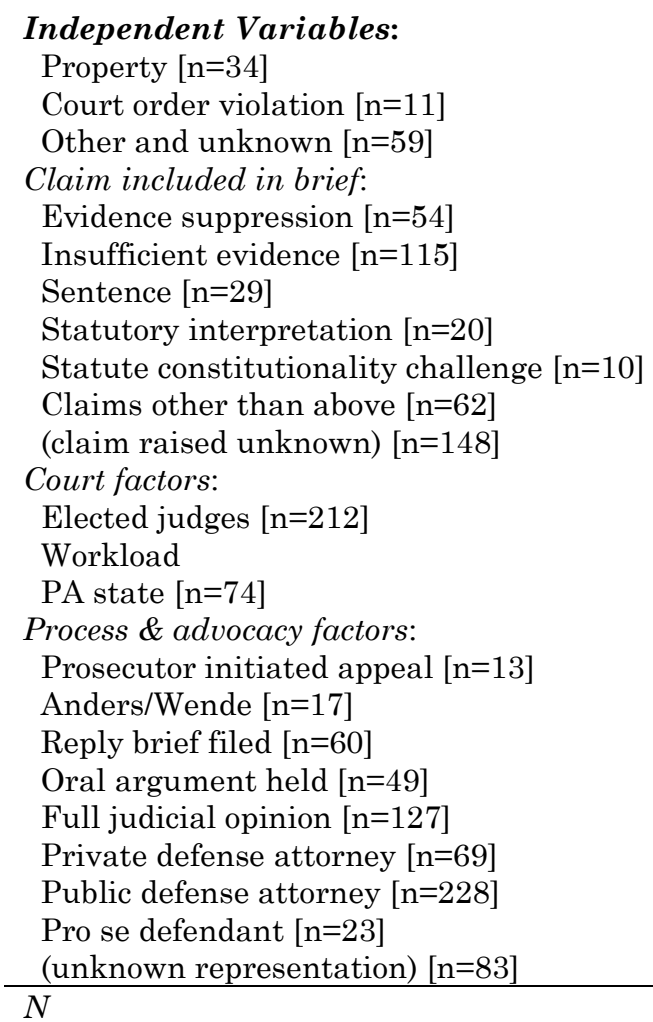

\begin{tabular}{cc}
\hline (1) & $(2)$ \\
\% cases w/ variable & \% cases w/o variable \\
receiving decision & receiving decision \\
favoring appellant & favoring appellant
\end{tabular}

SouRCE: Survey of State Court Criminal Appeals, 2010.

Most surprising was that these simple comparisons revealed the win rate for pro se appellants overall (13 percent) was equal to that for retained attorneys but slightly higher than the win rate for publicly funded counsel (12.3 percent). ${ }^{122}$

\section{Regression Results}

To investigate whether the relationships revealed in simple comparisons survived more sophisticated analyses, we used Heckman selection models. ${ }^{123}$ Comparing the descriptive findings (Table 3 ) with the

${ }^{122}$ See infra Table 5 (comparing misdemeanor to felony appeals). In comparing only appeals of right, the difference was even more pronounced, with pro se appellants winning 17.7 percent of the time-better than both appellants with public counsel (13.5 percent) and those with retained counsel (12.5 percent).

${ }^{123}$ A few variables from Tables 2 and 3 do not appear in the model because they lacked the variation needed for inclusion, including "court order violation" and "full judicial opinion." The "reply brief filed" and "oral argument held" variables were excluded from the merits model (first stage) but included in the succeeded model (second stage).

As Table 4 illustrates, a highly significant $r h o$ test statistic provides evidence of a selection effect, conditioned on an appeal receiving a full merits review. The rho test statistic achieved significance at the $p<0.01$ level. Additionally, unreported results from various 
regression results (Table 4) illustrates the dangers of relying on simple comparisons to estimate the importance of case features for complex case outcomes. For example, Table 3 suggests that misdemeanor appellants in Pennsylvania, the state with the most cases in the random sample, fared far worse than appellants in other states. After controlling for other factors, however, results in Table 4 imply that Pennsylvania appeals did not systematically vary from appeals in other states. We review the most interesting regression findings below, offering tentative explanations for each.

\section{a. Merits Review}

Analyses of merits review generated five notable findings. First, even after controlling for whether the appeal was of right or permissive, courts of last resort were significantly less likely to review misdemeanor appeals than intermediate courts, reflecting higher rates of dismissal for procedural error by high courts than by intermediate courts. Several jurisdictions limit appeals to high courts more strictly than intermediate courts, ${ }^{124}$ and perhaps these restrictions tripped up appellants.

Second, the relationship with a greater likelihood of merits review was much stronger for appeals that challenged convictions alone than for appeals that included challenges to sentences, when compared to appeals where the type of challenge was unknown. This finding comports with our expectation that appellate judges, like appellants, may be more concerned with errors underlying misdemeanor convictions than they are with misdemeanor sentencing. 125

Third, as predicted, appeals with identifiable claims were significantly more likely to receive merits review than the reference set of appeals in which claims could not be identified, ${ }^{126}$ with a single exception. Appeals including a constitutional challenge to a statute were significantly less likely to be reviewed on the merits compared to even those cases where the claim could not be determined. This is consistent with the hypothesis that such claims are often perceived to be clear losers not worth reviewing, raised only for preservation purposes in the hope that the constitutional rule might later be revised and applied retroactively to the defendant's case. ${ }^{127}$ Also, cases with insufficiency claims were not reviewed more than other claims, instead cases

\footnotetext{
alternatives to our models presented in Table 4, including modeling merits and appellate success in separate progit specifications, yield results that, while not identical to those reported in Table 4, do not meaningfully vary from them.

124 See, e.g., sources cited supra note 31.

125 See supra text accompanying note 76 .

${ }^{126}$ Claims were coded from briefs and were unavailable in many cases dismissed or denied review that were not briefed. Eighty-eight percent of unknown-claim cases were denied review, dismissed, or withdrawn without review on the merits.
}

127 See supra text accompanying notes 90-91. 
raising suppression and statutory interpretation were the most likely to receive merits review.

\section{Table 4: Selection Model: Appeal Succeeded, Conditioned on Merits REVIEW}

\begin{tabular}{|c|c|c|c|c|}
\hline & Merits & (s.e.) & Succeeded & (s.e.) \\
\hline \multicolumn{5}{|l|}{ Case specific variables: } \\
\hline Court of last resort & $-0.98 * *$ & $(0.34)$ & $-0.42 *$ & $(0.16)$ \\
\hline Mandatory review appeal & $1.17 * *$ & $(0.38)$ & -0.51 & $(0.38)$ \\
\hline \multicolumn{5}{|l|}{ Appeal from: } \\
\hline Conviction (alone) & $2.15 * *$ & $(0.41)$ & 0.83 & $(0.42)$ \\
\hline Sentence (included) & $1.18 * *$ & $(0.35)$ & $1.42 * *$ & $(0.53)$ \\
\hline (unknown/missing) [ref.] & --- & & --- & \\
\hline \multicolumn{5}{|l|}{ Crime type: } \\
\hline Drug trafficking, weapons & $-1.21 *$ & $(0.54)$ & 0.23 & $(0.56)$ \\
\hline Violence (homic., robb., assa.) & 0.04 & $(0.38)$ & 0.34 & $(0.34)$ \\
\hline Sex crime & 0.17 & $(0.45)$ & $1.52 * *$ & $(0.46)$ \\
\hline DUI [ref.] & --- & & --- & \\
\hline Drug possession & -0.86 & $(0.50)$ & -0.10 & $(0.45)$ \\
\hline Other driving related & 0.29 & $(0.42)$ & $0.81 * *$ & $(0.30)$ \\
\hline Property & -0.20 & $(0.42)$ & 0.42 & $(0.35)$ \\
\hline Other, missing & -0.22 & $(0.27)$ & -0.08 & $(0.32)$ \\
\hline \multicolumn{5}{|l|}{ Claim included in brief: } \\
\hline Evidence suppression & $2.87 * *$ & $(0.65)$ & -0.09 & $(0.33)$ \\
\hline Insufficient evidence & $1.42 * *$ & $(0.38)$ & 0.28 & $(0.37)$ \\
\hline Sentence & $2.02 * *$ & $(0.52)$ & 0.42 & $(0.35)$ \\
\hline Statutory interpretation & $2.65 * *$ & $(0.41)$ & -0.05 & $(0.32)$ \\
\hline Statute const. challenge & $-1.47 *$ & $(0.61)$ & -0.27 & $(0.68)$ \\
\hline Claims other than above & $0.81 *$ & $(0.34)$ & 0.08 & $(0.44)$ \\
\hline (Claim unknown) [ref.] & --- & & --- & \\
\hline \multicolumn{5}{|l|}{ Court factors: } \\
\hline Elected judges & $-0.78 *$ & $(0.36)$ & -0.28 & $(0.24)$ \\
\hline Workload & -0.00 & $(0.00)$ & -0.00 & $(0.00)$ \\
\hline PA state & 0.73 & $(0.63)$ & -0.38 & $(0.47)$ \\
\hline \multicolumn{5}{|l|}{ Process \& advocacy factors: } \\
\hline Prosecutor initiated appeal & 0.80 & $(0.50)$ & 1.49 * & $(0.60)$ \\
\hline Anders/Wende & 0.98 & $(0.67)$ & $-6.05 * *$ & $(0.39)$ \\
\hline Reply brief filed & --- & & 0.03 & $(0.14)$ \\
\hline Oral argument held & -- & & 0.52 & $(0.37)$ \\
\hline Private defense attorney & 0.01 & $(0.34)$ & 0.16 & $(0.40)$ \\
\hline Public defense attorney & 0.21 & $(0.35)$ & 0.25 & $(0.43)$ \\
\hline Pro se defendant & 0.04 & $(0.40)$ & 0.50 & $(0.41)$ \\
\hline (Unknown rep.) [ref.] & --- & & --- & \\
\hline Constant & $-1.49 *$ & $(0.61)$ & $-1.79 * *$ & $(0.61)$ \\
\hline Rho (Wald test) & & & $425.8 * *$ & \\
\hline Log likelihood & & & -154.8 & \\
\hline$N$ & 403 & & 260 & \\
\hline
\end{tabular}

NOTES: We report results from our selection model of an appeal's success and selection for full merits review. The dependent variable in the succeeded equation is whether the appellate court outcome favored the appellant (success is construed as something less than a full affirmance or dismissal and involved upsetting, to some degree, the lower court decision); the dependent variable in the merits equation is whether the appeal received a full merits review. Robust standard errors (clustered on the state level) are in parentheses. ${ }^{*} p<0.05 ;{ }^{* *} p<0.01$. We estimated the selection model using the "heckprob" command in Stata (v.15.1). SourcE: Survey of State Court Criminal Appeals, 2010. 
Fourth, misdemeanor appeals to courts with elected benches were significantly less likely to be heard on the merits than appeals to courts with appointed judges. This comports with the prediction that elected appellate judges may be less likely to disturb criminal convictions and sentences than judges selected by appointment. ${ }^{128}$

Fifth, surprisingly, courts were no more likely to review on the merits misdemeanor appeals filed by the prosecution than to review appeals by defendants, once other factors were controlled. Although simple comparisons revealed a pattern similar to felony appeals, ${ }^{129}$ with merits review provided in 43 percent of the prosecutor appeals but only 12 percent of the defense appeals, regression results uncover no significant difference based on who appeals. This finding implies that who seeks review actually may not matter in whether merits review is provided in misdemeanor cases and that other features may explain the differences in rates of review.

\section{b. Success among appeals reviewed on the merits}

Turning to what factors emerged as important to whether appeals reviewed on the merits succeeded in obtaining some form of relief, we discuss below the most interesting findings reported in Table 4.

When it comes to differences in success once a court considers a case on the merits, who appealed did matter. Among cases that did receive merits review, prosecutors were significantly more likely to succeed than defendants, as predicted. 130

Similarly, although appeals that included challenges to sentences were less likely to be reviewed on the merits than those challenging conviction alone, sentencing challenges that were reviewed on the merits were significantly more likely to succeed. Perhaps this is because sentencing error is easier to identify or less burdensome to correct, requiring only resentencing rather than the possibility of trial.

Crime type also mattered to an appeal's outcome. Sex-crime appeals accepted for merits review were associated with a higher likelihood of success

\footnotetext{
128 See supra text accompanying notes 79-81.

129 In our earlier examination of prosecutor appeals, which combined noncapital felony and misdemeanor appeals from the same NCSC dataset, we found that prosecutors enjoyed almost 50:50 odds of securing merits review for a discretionary felony appeal filed in a state high court (45.3 percent were reviewed on the merits). See King \& Heise, Appeals by the Prosecution, supra note 18, at 510. This was much higher than the 20:1 odds facing defendants who were seeking review of their felony cases in state high courts (4.6 percent reviewed on the merits). See Heise, King \& Heise, State Criminal Appeals, supra note 18, at 1948 tbl.2; King \& Heise, Appeals by the Prosecution, supra note 18, at 510. For more detailed comparison of misdemeanor and felony appeals, see infra Section IV.C.
}

130 See supra text accompanying notes 92-93. 
than other crime types, consistent with a potentially higher error rate in these cases or possibly more judicial concern about collateral consequences of conviction in these cases. Driving-related cases (other than DUIs) were also significantly associated with a higher likelihood of success, a result we had not predicted. These cases make up the largest category of misdemeanor prosecutions in many state trial courts but are underrepresented in the pool of cases that reach appellate courts. It is possible that selection decisions by appellants, counsel, and courts are particularly pronounced for the tiny proportion of these cases that reach appellate courts. Those that manage to reach the merits stage of review may raise more compelling claims of error than appeals of other crime types.

Although elected benches were less likely to grant review, ultimately the judicial-selection method was not significantly related to an appeal's success. The extent of a court's workload appeared unrelated to the likelihood of success in these misdemeanor cases as well, as we suspected, given their small number compared to other types of appeals. Except for the presence of an Anders-type statement, advocacy-related factors, including the presence of oral argument or a reply brief, did not achieve statistical significance. While these variables appear important in descriptive analyses, any independent statistical importance eroded once other factors were controlled.

As for type of representation, recall that simple descriptive comparisons suggested that misdemeanor appellants without counsel did better than those with counsel, particularly in mandatory appeals. Our regression analyses, which controlled for, among other factors, whether the appeal was mandatory or discretionary, did not find that representing oneself on appeal was significantly associated with greater success. ${ }^{131}$ To examine further whether pro se appellants enjoyed an advantage over represented defendants, our supplemental analyses substituted for the four different representation variables a single dummy variable comparing pro se appeals to all other types of representation. The absence of counsel remained insignificant. It appears that other characteristics of these pro se appeals may be responsible for their higher win rate.

\section{How Misdemeanor and Felony Appeals Differ}

This section discusses the comparison of misdemeanor appeals findings with those from our earlier research on defendants' felony appeals from the same NCSC Appeals Study. Because both sets of appeals were part of the

\footnotetext{
131 The regression, unlike column 1 in Table 3, included appeals filed by prosecutors and discretionary appeals, but it controlled for both. A sizeable portion (15-16 percent) of both misdemeanor and felony appeals were coded "unknown representation"; more cases were coded unknown than were coded pro se. Most of the "unknown representation" appeals were probably not pro se appeals but instead counseled appeals where it could not be determined from available documents if the attorney listed was retained or appointed.
} 
same random sample of direct appeal decisions in criminal cases from appellate courts nationwide, this comparison allows, for the first time, quantitative insights into how defendants' appeals in misdemeanor and felony cases differ.

\section{Differences in rates of success}

As to outcome, we did not anticipate whether misdemeanor appellants would lose or win more often than felony appellants, because hypotheses supporting both findings were plausible. As results in Table 5 illustrate, comparing the simple rates of success between felonies and misdemeanors, the rates appear almost identical. The misdemeanor success rate at the intermediate court of appeals level is 14.8 percent, very close to the 15.1 percent figure for felonies. ${ }^{132}$ At the high court level, the 8.3 percent win rate is close to the 7.7 percent for rate for felonies. ${ }^{133}$ Comparing win rates for cases with particular features-at least for comparisons involving more than ten misdemeanor cases-reveals that the association of most factors with a greater or lesser win rate is very similar for felony and misdemeanor appeals.

This consistency in success rates between misdemeanor and felony appeals is quite remarkable. But a few interesting differences surfaced as well, regarding insufficient evidence claims, advocacy efforts, and type of representation. For discretionary appeals but not appeals of right, felony appeals that included a claim challenging the sufficiency of evidence were twice as likely to win as misdemeanor appeals that included the same claim. This is somewhat inconsistent with the hypothesis that policing, prosecutorial screening, and judicial adherence to law are comparatively worse in misdemeanor cases. ${ }^{134}$ But for reasons detailed earlier, fewer wrongfully convicted defendants in misdemeanor cases may reach the appellate courts, especially if such defendants are more likely than wrongfully charged defendants in felony cases to plead guilty rather than take their cases to trial. ${ }^{135}$

Reply briefs appeared to assist appellants in mandatory appeals to a greater extent than in felony cases. They were associated with a 26 percent win rate for felony appellants, compared to misdemeanor cases, where appellants who filed reply briefs won only 19 percent of the time. For discretionary appeals, the presence of oral argument showed a similar difference benefiting felony appellants more than misdemeanor appellants. Additional opportunities for advocacy may be less influential in misdemeanor

\footnotetext{
132 See NCSC APPEALS STUDY, supra note 18, at 5 tbl.2.

133 See id. at 4 tbl.1.

134 See generally NATAPOFF, supra note 1.

135 See supra Section I.B.
} 
appellate litigation if that advocacy is, on average, less effective than the advocacy in felony litigation. 136

TABLE 5: SUMMARY OF VARIABLES, BY DECISION FAVORING APPELLANT, Comparing Misdemeanor AND FELONy APPEAls (W/Out SupPlemental or PROSECUTOR APPEALS)

\begin{tabular}{|c|c|c|c|c|}
\hline Independent Variables: & $\begin{array}{c}1) \\
\text { Mand. appeals } \\
\text { w/ variable, } \\
\% \text { w/ } \\
\text { decision } \\
\text { favoring } \\
\text { appellant } \\
\text { [Misdem.] }\end{array}$ & $\begin{array}{c}\text { (2) } \\
\text { Mand. appeals } \\
\text { w/ variable, } \\
\% \text { w/ } \\
\text { decision } \\
\text { favoring } \\
\text { appellant } \\
\text { [Felony] }\end{array}$ & $\begin{array}{c}\text { (3) } \\
\text { Disc. appeals } \\
\text { w/ variable, } \\
\% \text { w/ } \\
\text { decision } \\
\text { favoring } \\
\text { appellant } \\
\text { [Misdem.] }\end{array}$ & $\begin{array}{c}\text { (4) } \\
\text { COLR disc. } \\
\text { appeals w/ } \\
\text { variable, } \\
\% \mathrm{w} / \\
\text { decision favoring } \\
\text { appellant } \\
{[\text { Felony] }}\end{array}$ \\
\hline Court of last resort & 9.6 & 14.3 & 4.7 & $-\cdots$ \\
\hline \multicolumn{5}{|l|}{ Appeal from: } \\
\hline Conviction (alone) & 11.2 & 12.3 & 11.4 & 10.7 \\
\hline Sentence (included) & 27.5 & 20.5 & 4.2 & 6.8 \\
\hline (unknown) & 2.9 & 1.6 & 0.0 & 0.3 \\
\hline \multicolumn{5}{|l|}{ Crime type: } \\
\hline Drug trafficking, weapons & 15.4 & 16.6 & 0.0 & 6.2 \\
\hline Violence (hom., robb., assa.) & 13.5 & 13.3 & 0.0 & 3.2 \\
\hline Sex crime & 50.0 & 16.7 & 0.0 & 7.1 \\
\hline Drug possession & 4.6 & 12.8 & 3.6 & 6.8 \\
\hline Property & 15.4 & 17.5 & 12.5 & 6.3 \\
\hline Court order violation & 0.0 & 28.6 & 0.0 & 0.0 \\
\hline Other, missing & 12.2 & 0.0 & 0.0 & 0.0 \\
\hline \multicolumn{5}{|l|}{ Claim included in brief: } \\
\hline Evidence suppression & 10.2 & 15.8 & 0.0 & 27.8 \\
\hline Insufficient evidence & 16.0 & 16.9 & 12.5 & 25.9 \\
\hline Sentence & 25.0 & 21.7 & 100.0 & 11.8 \\
\hline Claims other than above & 13.2 & 14.4 & 20.0 & 39.4 \\
\hline (claim unknown) & 4.8 & 4.0 & 2.0 & 0.5 \\
\hline \multicolumn{5}{|l|}{ Court factors: } \\
\hline Elected judges & 10.3 & 15.3 & 3.9 & 3.6 \\
\hline \multicolumn{5}{|l|}{ Process \& advocacy factors: } \\
\hline Anders/Wende & 0.0 & 4.0 & --- & --- \\
\hline Reply brief filed & 19.0 & 26.1 & 0.0 & --- \\
\hline Oral argument held & 20.5 & 24.4 & 25.0 & 51.4 \\
\hline Full judicial opinion & 19.8 & 21.5 & 33.3 & 59.1 \\
\hline Private defense attorney & 12.5 & 18.8 & 0.0 & 2.6 \\
\hline Public defense attorney & 13.5 & 16.9 & 9.1 & 10.0 \\
\hline Pro se defendant & 17.7 & 2.9 & 0.0 & 0.0 \\
\hline (unknown represent.) & 7.0 & 7.1 & 2.6 & 1.0 \\
\hline$N$ & 270 & 2,080 & 120 & 1,153 \\
\hline
\end{tabular}

SouRCE: Survey of State Court Criminal Appeals, 2010.

Notes: Bolded percentages indicate $\mathrm{n}<10$, interpret with caution.

\footnotetext{
136 Another difference we found was that, among mandatory appeals, drug possession cases succeeded at a rate not far from the average for all crime types when the crime was a felony, but when the crime was a misdemeanor, such appeals succeeded at less than half the average rate. The reverse was true for property cases in discretionary appeals: appeals in felony property cases won at about the average rate, but appeals in misdemeanor property cases succeeded at twice the average rate.
} 
Perhaps the most interesting difference revealed in Table 5 concerns the relative success of mandatory appeals litigated pro se. The win rate for misdemeanor appellants in appeals of right without an attorney was 17.7 percent, a rate higher than the success rate for misdemeanor appellants in appeals of right with counsel. Among felony pro se appellants in appeals of right, by contrast, only 2.9 percent succeeded-far less than the rate for represented appellants. ${ }^{137}$ This does not necessarily mean that unrepresented misdemeanor appellants were better advocates than unrepresented felony appellants. Recall that the higher rate of success for pro se misdemeanor appeals did not survive more sophisticated analysis and that other factors related to these pro se appeals were apparently responsible for their higher win rate. 138

\section{Differences in representation mix}

We predicted that, as compared to felony appeals, misdemeanor appeals would include a higher percentage of defendant appellants represented by retained counsel and representing themselves; that is, that the proportion of appeals with publicly funded lawyers would be larger for felonies than for misdemeanors. ${ }^{139}$ What we find in Figure 2 comports with this expectation when comparing mandatory appeals (too many discretionary appeals were missing this information to permit testing). ${ }^{140}$

\footnotetext{
137 Unlike the impressive success rate of pro se misdemeanor of-right appellants, among felony appellants, "In no context did pro se defendants achieve a comparative advantage over defendants represented by legal counsel.” Heise, King \& Heise, State Criminal Appeals, supra note 18, at 1966.

138 See supra text accompanying note 131.

139 See supra text accompanying notes $46-51$ for a discussion of why so many misdemeanor defendants are convicted without counsel. Courts have rejected a federal constitutional right to publicly funded counsel on appeal for indigent misdemeanor defendants who lack a Sixth Amendment right to publicly funded counsel in the trial court. See, e.g., People v. Batiste, 167 Cal. Rptr. 171, 173 (Ct. App. 1980); State v. Vives, 50 Conn. L. Rptr. 309 (Super. Ct. 2010); State v. Castillo, 57 So. 3d 1012 (La. 2011) (upholding state constitutional provision denying appointment of counsel to indigent defendant convicted of petty misdemeanor traffic offense to assist him in the preparation of an application for discretionary review).

140 The data in Figures 2-5 are different than what appear in Table 4, which includes, in addition to defense appeals of right, prosecution appeals and discretionary appeals. Simple comparisons of representation-type proportions for discretionary appeals were complicated by the large number of discretionary appeals by defendants in both misdemeanor and felony cases that were coded "unknown representation" -31.7 percent of the misdemeanor appeals and 63.6 percent of the felony appeals. Documentation in cases that were denied review tended to reveal less information than documentation in cases decided on their merits.
} 
Figure 2. Type of Representation in Mandatory Appeals, Misdemeanor AND FELONY COMPARED

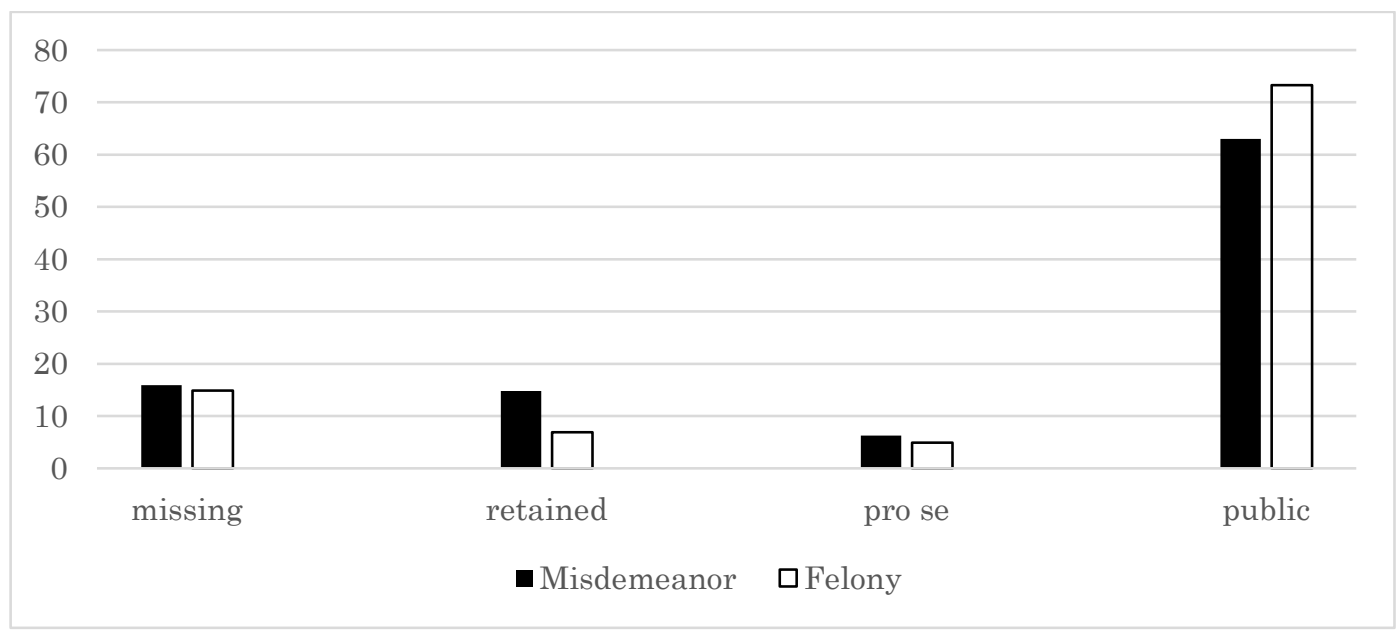

Source: Survey of State Court Criminal Appeals, 2010.

But the pattern differed by crime type, as Figures $3-5$ make clear. Among misdemeanor appeals, DUI cases had the highest percentage of retained counsel and the lowest percentage of publicly funded counsel among all crime type categories. ${ }^{141}$ By contrast, drug, weapons, and sex-offense appeals involved almost entirely publicly funded counsel. The category with the most pro se appellants, as expected, involved driving-related crimes, traffic offenses that constitute much of what are presumably the lowest-level misdemeanor offenses. More than one in four of these appeals were pro se, and among mandatory appeals, one in five appealed pro se.

${ }^{141}$ In the only published report of types of misdemeanor representation, HARLOW, supra note 50 , at 7 , reported the rate of retained attorneys by jail inmates and charge (both felony and misdemeanor): assault, 16.2 percent; larceny, 9.6 percent; drug possession, 15.7 percent; weapons, 25.0 percent; and DWI, 28.1 percent. 
King \& Heise 2-15 draft

Figure 3. Percentage Retained Counsel, Mandatory Appeals, Misdemeanor And FElOny COMPARED, By CRIME TyPe

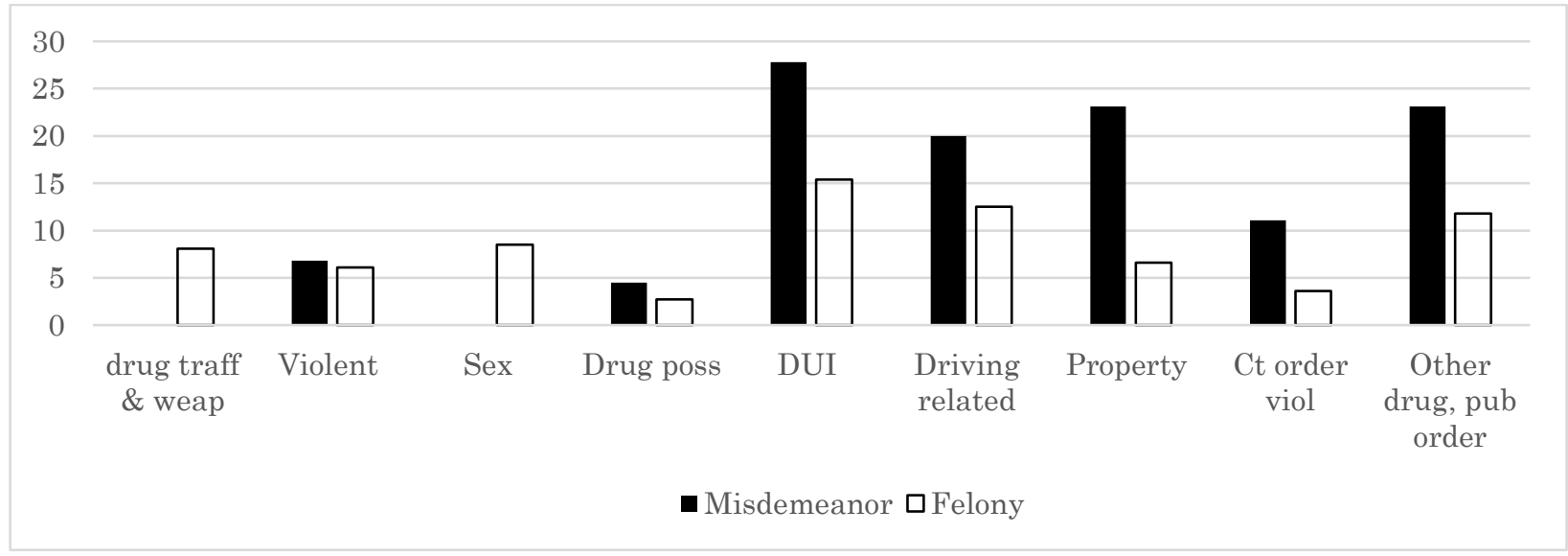

SouRcE: Survey of State Court Criminal Appeals, 2010.

Figure 4. Percentage Pro se, Mandatory Appeals, Misdemeanor and

FELONY COMPARED, BY CRIME TYPE

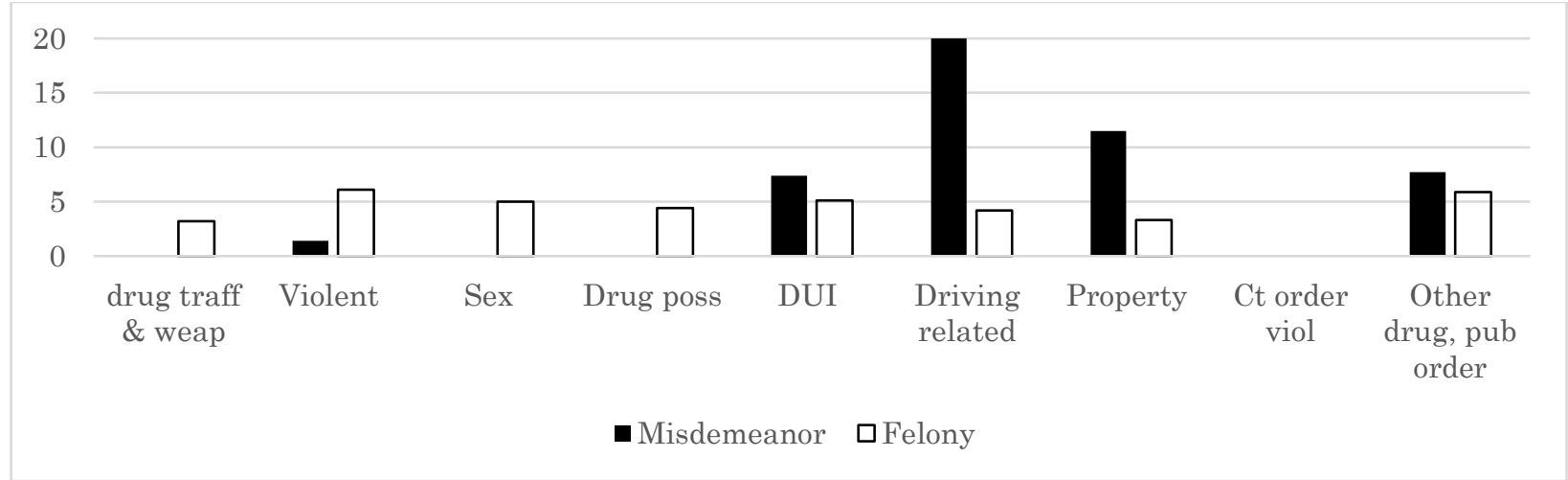

Source: Survey of State Court Criminal Appeals, 2010.

Figure 5. Percentage Publicly Funded Counsel, Mandatory Appeals, Misdemeanor AND FELONY COMPARED, BY CRIME TyPe

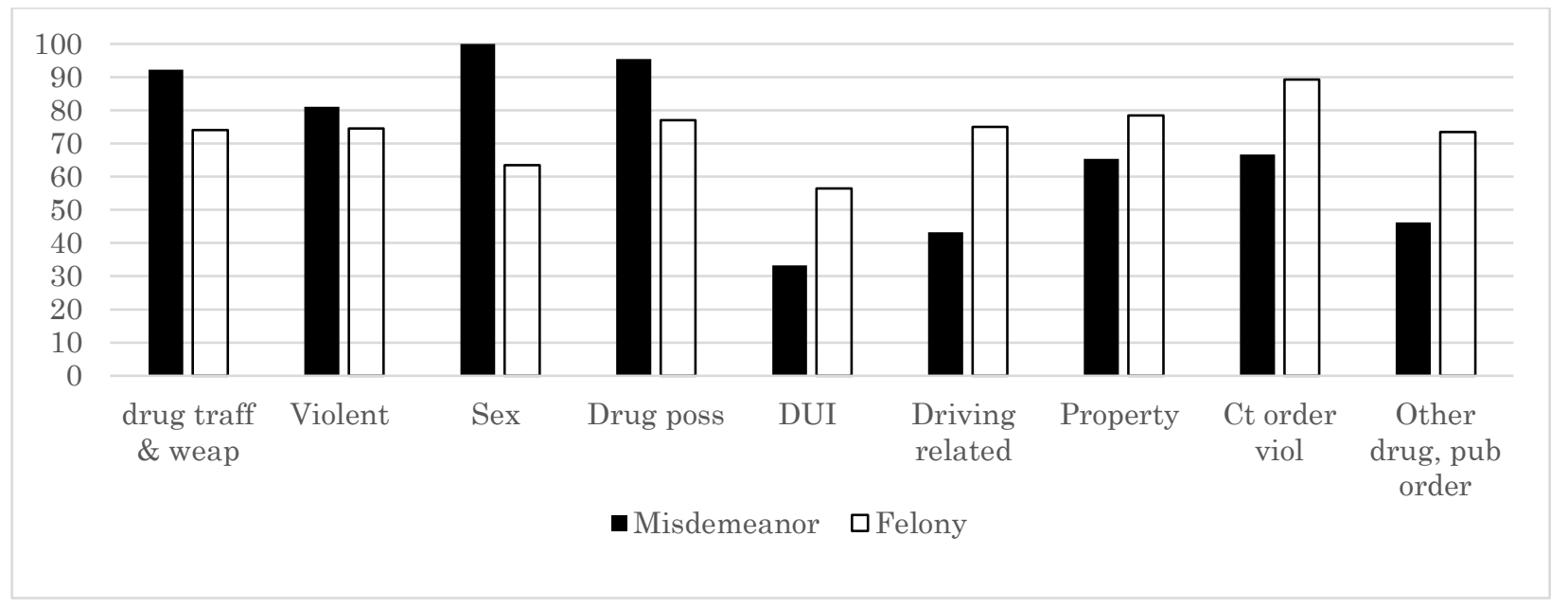




\section{Part V. Implications for Policy}

Professor Eve Primus reported that when she worked as a public defender, "I routinely had misdemeanor court judges refuse to address legal issues and tell me to save my legal arguments for appeal." 142 These trial judges knew that appellate review was such an exceptional event for misdemeanor cases that it was safe to ignore. Commentators have argued that any hope that appeal will provide judicial oversight and correction of error in these cases is wishful thinking. ${ }^{143}$ This study provides, for the first time, empirical testing of this claim. With an estimated average review rate of no more than eight in 10,000 convictions, and only one conviction or sentence out of every 10,000 misdemeanor judgments actually disturbed on appeal, it is no wonder that judges, prosecutors, and defense counsel can be confident that their conduct in trial court proceedings in misdemeanor cases will not be reviewed. At this rate, appellate review of misdemeanor-case processing cannot function as a serious remedy or deterrent for error. ${ }^{144}$

Appellate judges themselves might not share this impression of misdemeanor appeals. From their standpoint, review of misdemeanor cases may appear routine, not rare. After all, an estimated one in thirteen criminal appeals filed in state appellate courts nationwide are misdemeanor appeals. ${ }^{145}$ But the findings here suggest that not only is that a miniscule fragment of the millions of misdemeanors prosecutions churning through state trial courts, it is a systematically skewed sample as well.

One might argue that this level of review would be sufficient to correct error if error rates in misdemeanor cases are extremely low. However, error rates in misdemeanor cases are likely worse than in felony cases, not better. The sources of potential error begin with policing. Research has exposed, for example, how innocent people have been charged with drug and weapons misdemeanors based on inaccurate information from faulty forensic field tests

\footnotetext{
142 Eve Brensike Primus, Response, Our Broken Misdemeanor Justice System: Its Problems and Some Potential Solutions, 85 S. CAL. L. REV. PostSCRIPT 80, 81 (2012).

143 See id. at 81 (noting that "misdemeanor court judges are relatively insulated from higher court feedback and do not learn of their mistakes in the same way that felony trial court judges do"); Roberts, supra note 4646, at 337-40 (explaining why ineffective assistance challenges in misdemeanor cases are rarely appealed).
}

144 See, e.g., Malcolm M. Feeley, How to Think About Criminal Court Reform, 98 B.U. L. REV. 673, 709 (2018) ("I do not dispute the value of appellate courts clarifying constitutional criminal procedure - this is one of their important jobs. But to view this as a meaningful form of administrative oversight of the criminal [misdemeanor] process is, in my view, laughable and naïve in the extreme."). Examining a misdemeanor procedural statute recently for the first time, one court stated, "Not surprisingly, there is little appellate activity interpreting this statute as it applies only to the prosecutions of violations and misdemeanors in local criminal courts.” People v. Bollu, 83 N.Y.S.3d 794, 796 (Cty. Ct. 2018).

145 See NCSC APPEALS STUDY, supra note 18, at 5 tbl.2 (estimating 7.7\% of direct criminal appeals in 2010 were misdemeanors). 
and criminal records; 146 how arrest quotas have systematically produced baseless arrests for "order maintenance" misdemeanors, such as trespassing, loitering, failing to obey an officer, or "being a rogue and vagabond"; 147 and how courts, prosecutors, and police use misdemeanor charges and sentences to raise revenue. ${ }^{148}$ The processing of these charges compounds the problem. For those who are innocent, too often the burdens of getting to trial far exceed the expected costs of pleading guilty. Defendants often anticipate being found guilty at trial when it is the police officer's word versus their own. ${ }^{149}$ When harsh detention policies mandate bail they cannot afford to pay, and insisting on trial would mean waiting weeks or months more in jail, pleading guilty and accepting a sentence of "time served" appears to many defendants to be their only option to get out of jail.150 As Professor Eisha Jain has summarized, "Defendants systematically make the rational decision to minimize the length of their experiences with the process, rather than attempt to seek adjudication." 151 Compared to felonies, misdemeanors are resolved by judges and prosecutors with less experience and less time, with no counsel for the defense or overworked counsel at best, with fewer procedural protections, and less transparency, record-keeping, and accountability. ${ }^{152}$ In her thoughtful evaluation of misdemeanor crime's "innocence problem," Professor Alexandra Natapoff admits we don't know how many of those convicted of misdemeanors

146 NATAPOFF, supra note 1, at 87-98; Roberts, supra note 11, at 799-802.

${ }^{147}$ NATAPOFF, supra note 1 , at 59 ;

148 E.g., U.S. DeP’T OF JUstice, Civil Rights Div., InVEstigation of the Ferguson Police

DEPARTMENT 9-15 (2015), https://www.justice.gov/sites/default/files/opa/press-

releases/attachments/2015/03/04/ferguson_police_department_report.pdf . See generally

Eisha Jain, Capitalizing on Criminal Justice, 67 DUKE L.J. 1381 (2018) (explaining how municipalities benefit financially from various criminal justice policies).

149 Roberts, supra note 11 , at 812-13.

150 E.g., KOHLER-HAUSMANN, supra note 4, at 135 (noting "the time a defendant would wait [in jail] to push a case to trial is usually much longer than the jail term being offered if he or she agrees to take a plea"); NATAPOFF, supra note 1, at 87-91; Roberts, supra note 11, at 799-802, 833 (discussing the fifty-six misdemeanor drug possession exonerations in Harris County, Texas).

151 Jain, supra note 3, at 959-60. "[M]isdemeanor courts are . . functionally administrative systems," Professor Issa Kohler-Hausmann concluded, "where trials are rarely viable routes to dispute legal issues or establish factual innocence." KOHLER-HAUSMANN, supra note 4, at 263; see also Heaton, Mayson \& Stevenson, supra note 2, at 717 (reporting results of study finding Harris County, Texas, defendants who are detained on misdemeanor charges are 25 percent more likely to be convicted and 43 percent more likely to be sentenced to jail than similarly situated releasees); Emily Leslie \& Nolan G. Pope, The Unintended Impact of Pretrial Detention on Case Outcomes: Evidence from New York City Arraignments, 60 J.L. \& ECON. 529 (2017) (reporting misdemeanor defendants who are detained are more likely to plead guilty, be convicted, and be sentenced to incarceration than similarly situated defendants who are not detained).

152 See NATAPOFF, supra note 1, at 68-70, 87-90, 108-11; Alexandra Natapoff, Misdemeanors, 11 ANN. REV. L. \& Soc. SCI. 255, 256 (2015). 
are innocent. ${ }^{153}$ But there is mounting evidence that undercuts an assumption that there is substantially less error for appellate review to correct and deter in these cases than there is in felony cases.

The findings here suggest that the greatest need for more judicial attention is in cases involving charges for the lowest-level crime ending in guilty plea or dismissal. Appellate review is least effective as a mechanism for correcting errors and developing the law in three categories of misdemeanor cases: the lowest-level misdemeanor crimes for which appeal is not even authorized or is drastically limited; misdemeanor cases in which a defendant is arrested and detained but never convicted; and guilty plea cases, reviewed at an even lower rate than misdemeanor convictions that follow trial. It is in these cases where appeal is least likely that the problems plaguing misdemeanor enforcement are most pernicious.

Moreover, direct appeal of an individual conviction is too often an illsuited mechanism for addressing these problems. Direct appeal is unlikely to end policies and practices by police and lower courts designed to generate revenue rather than improve public safety; ${ }^{154}$ realign bail practices so that nondangerous, indigent defendants are not detained pretrial when they cannot afford money bail; ${ }^{155}$ direct resources to overworked appointed counsel and prosecutors who barely have enough time to negotiate a plea, much less investigate the facts; manage cases to reduce the number of times that lawyers and clients must be present in court, only to have a proceeding adjourned; 156 or curb the counterproductive collateral consequences that follow a misdemeanor arrest or charge, even when ultimately dismissed. ${ }^{157}$ These system-wide problems do not present claims a convicted defendant could raise on appeal, and they afflict the innocent and guilty alike. Given the volume of misdemeanor case processing and the nature of problems in need of oversight, even marginally increased access to appeal is unlikely to make an impact on what actually happens to those charged with misdemeanors in the nation's busiest trial courts. ${ }^{158}$

\footnotetext{
153 See NATAPOFF, supra note 1 , at 87-111.

${ }^{154}$ Cf. Beth A. Colgan, Graduating Economic Sanctions According to Ability to Pay, 103 IOWA L. REV. 53, 65-69 (2017) (addressing concerns that a system of graduated economic sanctions would decrease revenue generation).

155 E.g., Crystal S. Yang, Toward An Optimal Bail SYstem, 92 N.Y.U. L. Rev. 1399 (2017).

156 E.g., KOHLER-HAUSMANN, supra note 4, at 122-23, 137-38.

157 See, e.g., id. at 150-51; Beth A. Colgan, Fines, Fees, and Forfeiture, in 4 Reforming Criminal Justice, supra note 17, at 205, 225 (arguing that "cases resulting in the imposition of fines, fees, and forfeitures may be riddled with factual and constitutional issues which lay people are ill-suited to raise").

158 For similar reasons, expanding the right to counsel for those convicted misdemeanants who do appeal is not a likely priority for reform. Already those rare misdemeanor defendants who do reach appellate courts win as often as felony appellants, even though comparatively more of them are pro se. And our findings suggested that whether they
} 
Instead, a better alternative for judicial regulation of state misdemeanor cases may be providing opportunities to challenge the legality of misdemeanor procedures through means other than direct appeal. Lawsuits and class actions seeking injunctive relief and targeting oppressive sanctioning and detention policies have seen some success. ${ }^{159}$ These strategies, along with evidence-based, administrative and legislative reforms tailored to local circumstances, appear to be more promising avenues for change than expanding direct appeal could ever be. Findings like those in this Article, and hopefully in future studies, can help ensure that more than guesswork guides law and policy in the nation's most common criminal cases.

represented themselves, hired a lawyer, or had a publicly provided lawyer made little difference in the outcome of their appeals

159 See, e.g., Robinson v. Purkey, No. 3:17-CV-01263, 2018 WL 5023330, at *2 (M.D. Tenn.

Oct. 16, 2018) (granting preliminary injunction for class action plaintiffs challenging

Tennessee's policy of suspending the driver's licenses of those who fail to pay traffic tickets); Cain v. City of New Orleans, 281 F. Supp. 3d 624, 652-59 (E.D. La. 2017) (granting summary judgment on due process claims when judges assessed fees because "governing law ... force[d] the Judges to generate revenue from the criminal defendants they sentence," creating a substantial conflict of interest, and judges routinely imprisoned, without any ability-to-pay inquiry, indigent defendants for failure to pay court debts); Schultz v. State, 330 F.Supp.3d 1344 (N.D. Ala. 2018) (granting preliminary injunction in equal protection challenge to detention policy); Colgan, supra note 157, at 216-17. 


\section{Appendix A. Independent Variables}

\section{a. State- and Court-Specific Variables}

Mandatory/Discretionary Review; Court of Last Resort/Intermediate Appellate Court. Our data indicate for each appeal whether it was "of-right" (mandatory) or "by permission" (discretionary). We included a dummy variable signaling whether the appeal was mandatory, and another dummy variable identifying those appeals decided by state courts of last resort. ${ }^{1}$

State. Appendix Table 2 presents general information on the national sample of 403 misdemeanor appellate decisions from forty-six different states. Because 18.4 percent of those decisions are from Pennsylvania, we include a dummy variable for Pennsylvania appeals to test whether they systematically varied from appeals in other states. ${ }^{2}$

Layer of Appeal. To identify which appeals were reviewing the trial court record for the first time or were instead reviewing another decision that had itself reviewed that record, we attempted to determine, for each court in each state, whether review would have been on the record without new fact finding, or would have been de novo with new fact finding. ${ }^{3}$

Judicial-Selection Method. To test the possible significance of judicialselection method, we coded a specific appellate court as "elected" if the initial judicialselection method for the relevant court involved any form of election rather than appointment. ${ }^{4}$

Court Workload. To investigate whether higher caseloads might depress reversal rates, ${ }^{5}$ we constructed a continuous "workload" variable by dividing the total appellate filings in each court ${ }^{6}$ by the number of judges or justices on that particular court. ${ }^{7}$

\footnotetext{
${ }^{1}$ See supra notes 75-76 and accompanying text (discussing likely correlation between success and these two factors).

${ }^{2}$ In addition, insofar as a state's law informs appellate decisions within that state, we cannot plausibly assume that appellate decisions within a state are independent of one another. As such, our selection models, discussed infra Table 3, cluster by state.

3 This coding is available with the authors and was based on each state's law.

${ }^{4}$ See Heise, King \& Heise, State Criminal Appeals, supra note 18, at 1950; King \& Heise, Appeals by the Prosecution, supra note18, at 494; supra notes 79-81 and accompanying text. We also used an alternative measure of election: retention instead of initial selection. The results, not reported here, did not materially differ.

5 See supra note 78 and accompanying text.

${ }^{6}$ We used 2012 caseloads from the CSP, since 2010 caseload data were not available for every state. See Nat'l Ctr. for State Courts \& Conference of State Court Adm'rs, State Court Caseload Statistics, CT. STAT. PROJECT, http://www.courtstatistics.org/Other-Pages/StateCourtCaseloadStatistics.aspx (last visited Jan. 8, 2019) [https://perma.cc/RB22-NKRP].

${ }^{7}$ For judges per court, see Nat'l Ctr. for State Courts, List of Tables, ST. CT. ORG., https://www.ncsc.org/microsites/sco/home/List-Of-Tables.aspx (last visited Jan. 8, 2019)
} 
APPENDiX TABle 1: APPEALs AND SuCCEss, By STATE

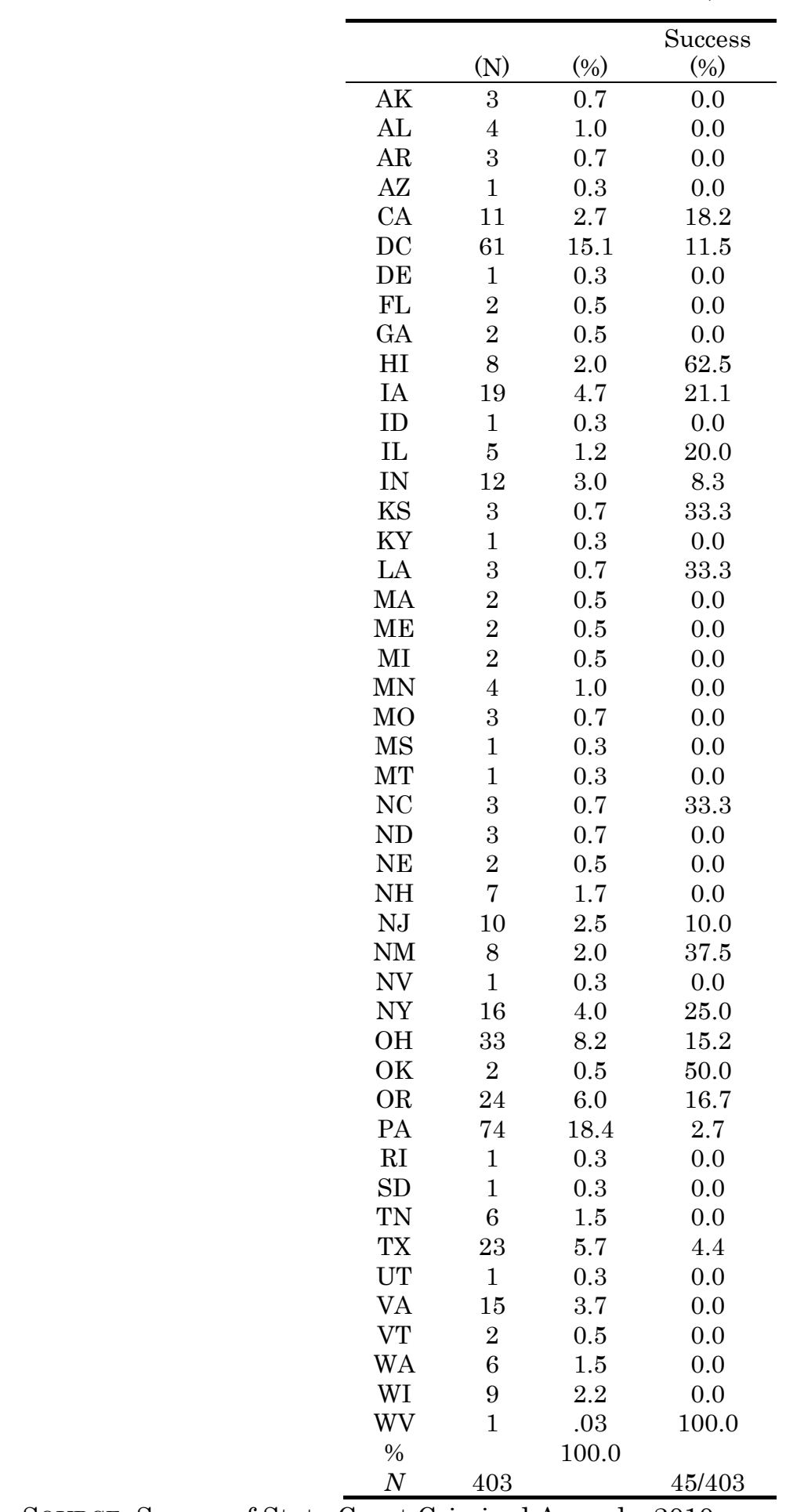

SOURCE: Survey of State Court Criminal Appeals, 2010.

[https://perma.cc/EXR8-DDS7] (follow "Number of Appellate Court Judges" hyperlink, numbered 2.2.a). 


\section{b. $\quad$ Crime Type and Claims Raised}

Crime Type and Appeal Type. To investigate our various hypotheses about the relationship between crime of conviction and appellate success, ${ }^{8}$ we collapsed the twenty-four different crime types available in the data into nine categories: (1) drug trafficking, weapons; (2) violence; (3) sex; (4) DUI; (5) other driving related; (6) drug possession; (7) property; (8) court order violations; and (9) all other crimes combined with cases missing this information. ${ }^{9}$ To assess whether sentence appeals correspond with a greater likelihood of success than appeals from conviction alone, we include a dummy variable indicating whether the appeal included a challenge to the sentence and another that tracked whether the appeal challenged only the conviction. ${ }^{10}$

Claim(s) Included in Brief. To examine the significance of claim type, ${ }^{11}$ we condensed the claim categories in the data into seven categories: (1) insufficient evidence; (2) evidence suppression; (3) sentence related ${ }^{12}$; (4) statutory interpretation; (5) statute challenged on constitutional grounds; (6) other claims (including, most prominently, claims relating to jury instructions, prosecutorial misconduct, and ineffective counsel); and (7) unknown claims. Cases in which the claims are unknown serve as the interpretative reference category, which we expected to have a lower rate of relief than other categories because claims information was coded only for cases in which that information was available in briefs, and many cases terminated before merits review had not been briefed.

\section{c. Advocacy-Related Variables}

Prosecutor-Initiated Appeal. To detect how prosecutor appeals may have differed from defense appeals, ${ }^{13}$ we include a dummy variable identifying those misdemeanor appeals initiated by a prosecutor. ${ }^{14}$

Type of Defense Representation. We anticipated that (1) pro se defendants would fare worse than represented defendants and (2) retained counsel would perform better than publicly funded counsel (assuming that losing cases are less

\footnotetext{
8 See supra notes 82-84 and accompanying text.

${ }^{9}$ Both DUI and drug-possession convictions made up a very large percentage of appeals and warranted study for that reason alone. In addition, drug-possession and court-order violations had particularly low rates of success in simple comparisons. We settled on DUI appeals as our reference category for our statistical models because their success rate is close to average for the entire sample and thus provides a helpful benchmark for interpretive and comparative purposes.

10 The references for these two dummy variables are cases in which the part of the judgment appealed from was unknown or missing.

11 See supra text accompanying notes 85-89.

12 The NCSC Appeals Study included both a variable for "appeal from sentence" and several sentence-related claim variables. See NCSC APPEALS STUDY, supra note 18, at 5-6. Because the claim variables were coded in only cases that were briefed, the number of cases missing information about claim type exceeds the number of cases missing information about whether the appeal is from sentence or conviction or both. See id.
}

13 See supra text accompanying notes 92-94.

${ }^{14}$ Among our 403 misdemeanor appeals, thirteen (or 3.2 percent) were initiated by prosecutors. 
likely to be pursued when the defendant is paying) or worse (if publicly funded attorneys have more experience and expertise). ${ }^{15}$ To investigate this possibility, we created three dummy variables that signal the presence of pro se, publicly funded, ${ }^{16}$ and retained representation, respectively. ${ }^{17}$

Anders Statements. To assess whether appeals were more likely to lose when publicly funded counsel filed an Anders-type statement that no meritorious issues existed, ${ }^{18}$ we created a dummy variable signaling the presence of an Anders brief or statement in an appeal.

Reply Briefs and Oral Arguments. To examine whether appellants who filed replies or had the chance to argue their case before the court were more likely to succeed on appeal than those who did not, ${ }^{19}$ we included a dummy variable indicating the filing of a reply brief and another indicating the presence of oral argument.

\footnotetext{
15 See supra notes 101-103 and accompanying text.

${ }^{16}$ Information distinguishing defenders from appointed private attorneys was not available.

17 The reference for each variable is the category of cases missing information on the type of representation for the defendant. Most of the discretionary appeals to courts of last resort that were denied review lacked any representation information. NCSC researchers suggested to us that these missing values likely reflect the inability to determine whether the attorney listed for the appellant was retained or publicly funded.

18 See supra text accompanying notes 99-100.

19 See supra text accompanying note 104.
} 
Appendix B: Estimated Misdemeanor Conviction Rate Derivation

\begin{tabular}{|c|c|c|c|c|c|}
\hline State & $\begin{array}{l}\text { Jurisdictional } \\
\text { Scope }\end{array}$ & Calculation & $\begin{array}{l}\text { Scope of } \\
\text { Misdemeanors }\end{array}$ & Source & $\%$ \\
\hline Alaska & Statewide & $\begin{array}{l}\text { Sum of guilty pleas }(10,855) \\
\text { and guilty verdicts at trial } \\
\text { (100), divided by total } \\
\text { disposed }(19,217) \text {. }\end{array}$ & $\begin{array}{l}\text { All (including } \\
\text { traffic } \\
\text { violations) }\end{array}$ & $\begin{array}{l}\text { ALASKA COURT SYS., } \\
\text { ANNUAL REPORT FY } \\
\text { 2018, at } 137 \text { (2018), } \\
\text { https://public.courts.al } \\
\text { aska.gov/web/admin/do } \\
\text { cs/fy18.pdf. }\end{array}$ & 57 \\
\hline Cal. & Statewide & $\begin{array}{l}\text { Sum of pretrial guilty pleas } \\
\text { (195,415 nontraffic, } 163,197 \\
\text { traffic) and bail forfeitures } \\
\text { (1,346 nontraffic, } 5,764 \\
\text { traffic), divided by total } \\
\text { pretrial dispositions ( } 310,936 \\
\text { nontraffic, } 211,937 \text { traffic). } \\
\text { California does not report } \\
\text { whether trial dispositions } \\
\text { (only } 1 \% \text { of all cases) are } \\
\text { convictions or acquittals. }\end{array}$ & $\begin{array}{l}\text { All (nontraffic } \\
\text { and traffic) }\end{array}$ & $\begin{array}{l}\text { JUDICIAL COUNCIL OF } \\
\text { CAL., 2018 COURT } \\
\text { STATISTICS REPORT 70, } \\
100 \text { (2018), } \\
\text { http://www.courts.ca.g } \\
\text { ov/documents/2018- } \\
\text { Court-Statistics- } \\
\text { Report.pdf. }\end{array}$ & 70 \\
\hline D.C. & Districtwide & $\begin{array}{l}\text { Sum of guilty pleas (2,689 } \\
\text { U.S., } 232 \text { D.C., } 2,111 \text { traffic), } \\
\text { guilty jury verdicts (3 U.S., } 0 \\
\text { D.C., } 4 \text { traffic), and guilty } \\
\text { bench judgments ( } 367 \text { U.S., } 9 \\
\text { D.C., } 44 \text { traffic), divided by } \\
\text { total dispositions (9,260 U.S., } \\
\text { 1,230 D.C., } 4,184 \text { traffic). }\end{array}$ & $\begin{array}{l}\text { All (U.S., } \\
\text { D.C., and } \\
\text { traffic) }\end{array}$ & $\begin{array}{l}\text { D.C. COURTS, } \\
\text { STATISTICAL SUMMARY } \\
12(2017) \text {, } \\
\text { https://www.dccourts.g } \\
\text { ov/about/organizationa } \\
\text { l-performance/annual- } \\
\text { reports. }\end{array}$ & 37 \\
\hline Fla. & Statewide & $\begin{array}{l}\text { Sum of pretrial pleas } \\
(149,791) \text {, posttrial pleas }(213 \\
\text { nonjury, } 81 \text { jury), and posttrial } \\
\text { convictions ( } 271 \text { nonjury, } 518 \\
\text { jury), divided by total } \\
\text { dispositions }(256,865) \text {. }\end{array}$ & $\begin{array}{l}\text { Excludes DUI } \\
\text { and other } \\
\text { traffic }\end{array}$ & $\begin{array}{l}\text { OFFICE OF THE STATE } \\
\text { COURTS ADM'R, FLA. } \\
\text { COURTS, TRIAL COURT } \\
\text { STATISTICAL } \\
\text { REFERENCE GUIDE: } \\
\text { COUNTY CRIMINAL } \\
\text { STATISTICS 7-16 (2017), } \\
\text { http://www.flcourts.org } \\
\text { /core/fileparse.php/541/ } \\
\text { urlt/Chapter- } \\
\text { 7_County- } \\
\text { Criminal.pdf. }\end{array}$ & 59 \\
\hline Haw. & Statewide & $\begin{array}{l}\text { Convictions }(15,413) \text { (likely } \\
\text { includes pleas, but unclear), } \\
\text { divided by total misdemeanors } \\
\text { terminated }(27,914) \text {. }\end{array}$ & $\begin{array}{l}\text { Excludes } \\
\text { traffic }\end{array}$ & $\begin{array}{l}\text { HAWAI' STATE } \\
\text { JUDICIARY, ANNUAL } \\
\text { REPORT STATISTICAL } \\
\text { SUPPLEMENT tbl.22 } \\
\text { (2018), } \\
\text { https://www.courts.stat } \\
\text { e.hi.us/wp- } \\
\text { content/uploads/2019/0 } \\
\text { 1/2018_Annual_Report } \\
\text { _Stats_Supplement.pdf }\end{array}$ & 55 \\
\hline Ill. & Cook Cty. & $\begin{array}{l}\text { Data for the years } 2011-15, \\
\text { provided to Injustice Watch by } \\
\text { the Illinois Office of the State's } \\
\text { Attorney. Data reported as "no } \\
\text { more than } 56 \text { percent" during } \\
\text { time period. }\end{array}$ & Not specified & $\begin{array}{l}\text { ISSA KOHLER- } \\
\text { HAUSMANN, } \\
\text { MISDEMEANORLAND: } \\
\text { CRIMINAL COURTS AND } \\
\text { SOCIAL CONTROL IN AN } \\
\text { AGE OF BROKEN } \\
\end{array}$ & 56 \\
\hline
\end{tabular}




\begin{tabular}{|c|c|c|c|c|c|}
\hline & & & & $\begin{array}{l}\text { WINDOWS POLICING } 270 \\
\text { n. } 6(2018) .\end{array}$ & \\
\hline Ind. & Statewide & $\begin{array}{l}\text { Total guilty pleas }(74,956) \text {, } \\
\text { divided by total dispositions } \\
\text { (138,378) (trial outcomes are } \\
\text { unknown but still counted in } \\
\text { total dispositions). }\end{array}$ & All & $\begin{array}{l}\text { IND. JUDICIAL BRANCH, } \\
2017 \text { METHODS OF } \\
\text { DISPOSITIONS } 160 \\
\text { (2017), } \\
\text { https://www.in.gov/judi } \\
\text { ciary/iocs/files/rpts-ijs- } \\
\text { 2017-methods-of- } \\
\text { disposition.pdf. }\end{array}$ & 54 \\
\hline Kan. & Statewide & $\begin{array}{l}\text { Sum of pretrial guilty pleas } \\
(7,632) \text { and guilty verdicts } \\
\text { (188), divided by total } \\
\text { dispositions }(14,365) .\end{array}$ & All & $\begin{array}{l}\text { KAN. JUDICIAL BRANCH, } \\
\text { ANNUAL REPORT OF THE } \\
\text { COURTS OF KANSAS } \\
(2018), \\
\text { http://web.kscourts.org } \\
/ \text { stats/18/18\%20T\%20O } \\
\text { F\%20C\%20for\%20web. } \\
\text { pdf. }\end{array}$ & 54 \\
\hline Ky. & Statewide & $\begin{array}{l}\text { Sum of guilty dispositions in } \\
\text { district courts ( } 17,587 \text { first } \\
\text { offense, } 4,044 \text { second offense, } \\
1,161 \text { third offense) and circuit } \\
\text { courts ( } 1,698 \text { first offense, } 416 \\
\text { second offense, } 178 \text { third } \\
\text { offense), divided by sum of } \\
\text { total dispositions in district } \\
\text { courts ( } 30,128 \text { first offense, } \\
6,664 \text { second offense, } 2,211 \\
\text { third offense) and circuit } \\
\text { courts (2,053 first offense, } 504 \\
\text { second offense, } 219 \text { third } \\
\text { offense). Kentucky tracks } \\
\text { DUIs by number of offenses in } \\
\text { last ten years, each of which } \\
\text { carries different sentences; the } \\
\text { first three are misdemeanors. }\end{array}$ & DUI only & $\begin{array}{l}\text { ADMIN. OFFICE OF THE } \\
\text { COURTS, KY. COURT OF } \\
\text { JUSTICE, CIRCUIT } \\
\text { COURT - DUI REPORT } \\
\text { 121-23 (2018), } \\
\text { https://courts.ky.gov/ao } \\
\text { c/statisticalreports/Doc } \\
\text { uments/INSDUI524.pd } \\
\text { f; ADMIN. OFFICE OF } \\
\text { THE COURTS, KY. } \\
\text { COURT OF JUSTICE, } \\
\text { DISTRICT COURT - DUI } \\
\text { REPORT 122-23 (2018), } \\
\text { https://courts.ky.gov/ao } \\
\text { c/statisticalreports/Doc } \\
\text { uments/INSDUI511.pd } \\
\text { f. }\end{array}$ & 60 \\
\hline Md. & Statewide & $\begin{array}{l}\text { Total guilty }(4,995) \text {, divided by } \\
\text { total dispositions }(20,715) \text {. }\end{array}$ & DWI only & $\begin{array}{l}\text { COURT OPERATIONS } \\
\text { DEP'T, MD. JUDICIARY, } \\
\text { STATISTICAL ABSTRACT } \\
\text { 2017, at } 42 \text { (2018), } \\
\text { https://www.courts.stat } \\
\text { e.md.us/sites/default/fil } \\
\text { es/import/publications/ } \\
\text { annualreport/reports/2 } \\
\text { 017/fy2017statisticalab } \\
\text { stract.pdf. }\end{array}$ & 24 \\
\hline Mich. & Statewide & $\begin{array}{l}\text { Sum of guilty pleas in district } \\
\text { court }(108,427) \text { and municipal } \\
\text { court }(183) \text {, divided by sum of } \\
\text { total dispositions in district } \\
\text { court }(275,336) \text { and municipal } \\
\text { court }(455) \text {. }\end{array}$ & Nontraffic & $\begin{array}{l}\text { Caseload Reports, } \\
\text { MicH. CTs. (2017), } \\
\text { https://courts.michigan } \\
\text { gov/education/stats/Ca } \\
\text { seload/Pages/2017- } \\
\text { Caseload-Reports.aspx. }\end{array}$ & 39 \\
\hline Minn. & Hennepin Cty. & $\begin{array}{l}\text { Sum of total convictions ( } 712 \\
\text { "person," } 12,626 \text { other), } \\
\text { divided by sum of total } \\
\text { dispositions (1,902 "person," } \\
22,051 \text { other). }\end{array}$ & $\begin{array}{l}\text { All } \\
\text { (nonfelonies) }\end{array}$ & $\begin{array}{l}\text { MATTHEW A. JOHNSON, } \\
\text { MINN. JUDICIAL } \\
\text { BRANCH, FOURTH } \\
\text { JUDICIAL DISTRICT OF } \\
\text { MINNESOTA ADULT } \\
\text { DISPOSITION STUDY } 45 \\
\text { tbl.A1 (2015), }\end{array}$ & 56 \\
\hline
\end{tabular}




\begin{tabular}{|c|c|c|c|c|c|}
\hline & & & & $\begin{array}{l}\text { http://www.mncourts.g } \\
\text { ov/mncourtsgov/media/ } \\
\text { fourth_district/docume } \\
\text { nts/Research/Adult- } \\
\text { Level-Dispositional- } \\
\text { Analysis.pdf. }\end{array}$ & \\
\hline Mo. & Statewide & $\begin{array}{l}\text { Data reports the guilty plea } \\
\text { rate. Both "bench trial" }(0.4 \%) \\
\text { and "other" categories were } \\
\text { excluded from this calculation. }\end{array}$ & $\begin{array}{l}\text { Excludes } \\
\text { traffic } \\
\text { violations and } \\
\text { reviews of } \\
\text { ordinance and } \\
\text { municipal } \\
\text { dispositions }\end{array}$ & $\begin{array}{l}\text { Mo. Courts, Missouri } \\
\text { Judicial Report } \\
\text { Supplement } 23 \text { (2017), } \\
\text { https://www.courts.mo. } \\
\text { gov/file.jsp?id=122404. }\end{array}$ & 65 \\
\hline N.M. & Statewide & $\begin{array}{l}\text { Sum of district court } \\
\text { misdemeanor convictions ( } 20 \\
\text { trial, } 8 \text { plea at trial, } 394 \text { plea } \\
\text { before trial) and magistrate } \\
\text { court misdemeanor } \\
\text { convictions ( } 3,446 \text { trial, } 1,641 \\
\text { plea at trial, } 59,893 \text { plea } \\
\text { before trial), divided by sum of } \\
\text { total misdemeanor } \\
\text { dispositions ( } 879 \text { district } \\
\text { court, } 128,698 \text { magistrate } \\
\text { court). }\end{array}$ & $\begin{array}{l}\text { District court } \\
\text { (DWI/DUI and } \\
\text { other) and } \\
\text { magistrate } \\
\text { court } \\
\text { (domestic } \\
\text { violence, DWI, } \\
\text { traffic, and } \\
\text { other) }\end{array}$ & $\begin{array}{l}\text { N.M. JUDICIARY, } \\
\text { STATISTICAL } \\
\text { ADDENDUM TO THE } \\
\text { 2017 ANNUAL REPORT } \\
\text { 19, } 71 \text { (2017), } \\
\text { HTTPS://WWW.NMCOURT } \\
\text { S.GOV/UPLOADS/FILES/2 } \\
\text { 017\%20STATISTICAL\%2 } \\
\text { 0ADDENDUM\%20FINAL. } \\
\text { PDF. }\end{array}$ & 50 \\
\hline N.Y. & Statewide & $\begin{array}{l}\text { Sum of convictions } 2013-17 \\
\text { (915,748), divided by sum of } \\
\text { total dispositions } 2013-17 \\
(1,694,958) \text {. }\end{array}$ & All & $\begin{array}{l}\text { N.Y. STATE DIV. OF } \\
\text { CRIMINAL JUSTICE } \\
\text { SERVS., NEW YoRK } \\
\text { STATE ADULT ARRESTS } \\
\text { DisPOSED } 5 \text { (2018), } \\
\text { http://www.criminaljus } \\
\text { tice.ny.gov/crimnet/ojs } \\
\text { a/dispos/nys.pdf. }\end{array}$ & 54 \\
\hline N.C. & Statewide & $\begin{array}{l}\text { Sum of convictions in superior } \\
\text { court ( } 223 \text { verdict, } 12 \text { plea } \\
\text { before verdict, } 133 \text { plea no } \\
\text { contest to lesser, } 5947 \text { plea no } \\
\text { contest) and district court } \\
\text { (9,941 verdict, } 336 \text { guilty plea, } \\
124,252 \text { plea no contest), } \\
\text { divided by sum of total } \\
\text { dispositions ( } 20,478 \text { superior } \\
\text { court, } 434,092 \text { district court). }\end{array}$ & $\begin{array}{l}\text { nontraffic and } \\
\text { DWI }\end{array}$ & $\begin{array}{l}\text { N.C. JUDICIAL BRANCH, } \\
\text { STATISTICAL AND } \\
\text { OPERATIONAL REPORT } \\
\text { OF THE NORTH } \\
\text { CAROLINA TRIAL } \\
\text { COURTS: 2017-18, at 5, } \\
7 \text { (2019), } \\
\text { https://www.nccourts.g } \\
\text { ov/assets/documents/p } \\
\text { ublications/2017- } \\
\text { 18_trial_courts_statisti } \\
\text { cal_and_operational_re } \\
\text { port.pdf. }\end{array}$ & 31 \\
\hline Ohio & Statewide & $\begin{array}{l}\text { Sum of guilty pleas in } \\
\text { municipal court }(108,239) \text { and } \\
\text { county court }(6,148) \text {, divided } \\
\text { by sum of total dispositions in } \\
\text { municipal court }(242,316) \text { and } \\
\text { county court }(10,942) .\end{array}$ & $\begin{array}{l}\text { All (guilty } \\
\text { pleas to } \\
\text { original and } \\
\text { reduced } \\
\text { charges) }\end{array}$ & $\begin{array}{l}\text { SUPREME COURT OF } \\
\text { OHIO, OHIO COURTS } \\
\text { STATISTICAL REPORT } \\
\text { 176, } 236 \text { (2017), } \\
\text { http://www.supremeco } \\
\text { urt.ohio.gov/Publicatio } \\
\text { ns/annrep/17OCSR/20 } \\
\text { 17OCSR.pdf. }\end{array}$ & 45 \\
\hline $\mathrm{Pa}$. & $\begin{array}{l}\text { Philadelphia } \\
\text { and Miami- } \\
\text { Dade, trial } \\
\text { courts }\end{array}$ & $\begin{array}{l}\text { Conviction rates for } \\
\text { misdemeanor-only charges, } \\
\text { averaged (and weighted by } \\
\text { total observations in each } \\
\text { category). }\end{array}$ & Not specified & $\begin{array}{l}\text { Will Dobbie et al., The } \\
\text { Effects of Pre-Trial } \\
\text { Detention on } \\
\text { Conviction, Future } \\
\text { Crime, and }\end{array}$ & 54 \\
\hline
\end{tabular}




\begin{tabular}{|c|c|c|c|c|c|}
\hline & & & & $\begin{array}{l}\text { Employment: Evidence } \\
\text { from Randomly } \\
\text { Assigned Judges, } 108 \\
\text { AM. EcON. REV. } 201 \\
\text { online app. at } 1 \text { (2018), } \\
\text { https://assets.aeaweb.o } \\
\text { rg/assets/production/fil } \\
\text { es/6277.pdf. }\end{array}$ & \\
\hline S.D. & Statewide & $\begin{array}{l}\text { Sum of guilty pleas }(5,395) \\
\text { and trial convictions }(57), \\
\text { divided by total dispositions } \\
(10,841) \text {. }\end{array}$ & $\begin{array}{l}\text { First and } \\
\text { second offense } \\
\text { DUI }\end{array}$ & $\begin{array}{l}\text { S.D. UNIFIED JUDICIAL } \\
\text { SYSTEM, DUI FILINGS } \\
\text { AND DISPOSITIONS } 15 \\
\text { (2017), } \\
\text { http://ujs.sd.gov/upload } \\
\text { s/annual/fy2017/2017D } \\
\text { UIFilingsDispositionsS } \\
\text { tatewideByCounty.pdf. }\end{array}$ & 50 \\
\hline Tex. & Statewide & $\begin{array}{l}\text { Sum of convictions in district } \\
\text { court }(1,342) \text {, county court } \\
(187,988) \text {, and justice and } \\
\text { municipal court }(743,142) \text {, } \\
\text { divided by sum of total } \\
\text { dispositions in district court } \\
\text { ( } 3,485 \text {, excluding motions to } \\
\text { revoke), county court ( } 420,637 \text {, } \\
\text { excluding motions to revoke), } \\
\text { and justice and municipal } \\
\text { court ( } 1,009,589 \text {, court } \\
\text { appearance or trial). }\end{array}$ & $\begin{array}{l}\text { All district } \\
\text { and county } \\
\text { court } \\
\text { misdemeanors } \\
\text {; for justice } \\
\text { and municipal } \\
\text { courts, only } \\
\text { non-parking } \\
\text { traffic, } \\
\text { nontraffic } \\
\text { penal code, } \\
\text { and state } \\
\text { nontraffic } \\
\text { other }\end{array}$ & $\begin{array}{l}\text { OFFICE OF COURT } \\
\text { ADMIN., TEX. JUDICIAL } \\
\text { BRANCH, ANNUAL } \\
\text { STATISTICAL REPORT } \\
\text { FOR THE TEXAS } \\
\text { JUDICIARY app. at } 9,45 \text {, } \\
48 \text { (2018), } \\
\text { http://www.txcourts.go } \\
\text { v/media/1443455/2018- } \\
\text { ar-statistical-final.pdf. }\end{array}$ & 65 \\
\hline Vt. & Statewide & $\begin{array}{l}\text { Guilty pleas }(6,003) \text {, divided } \\
\text { by total }(10,838, \text { excluding } \\
\text { unknown trial outcomes and } \\
\text { "invalid or missing" category). }\end{array}$ & All & $\begin{array}{l}\text { Vt. Judiciary, Annual } \\
\text { Statistical Report for } \\
\text { FY18, at } 33 \text { (2018), } \\
\text { https://www.vermontju } \\
\text { diciary.org/sites/defaul } \\
\text { t/files/documents/FY18 } \\
\text { \%20Annual\%20Statisti } \\
\text { cal\%20Report\%200107 } \\
\text { 19.pdf. }\end{array}$ & 55 \\
\hline Wash. & Statewide & $\begin{array}{l}\text { Sum of convictions and guilty } \\
\text { pleas in superior court }(4,086) \\
\text { and lower courts }(54,078 \\
\text { guilty, } 20 \text { bail forfeit), divided } \\
\text { by total dispositions }(14,524 \\
\text { superior court, } 124,405 \text { lower } \\
\text { courts). }\end{array}$ & $\begin{array}{l}\text { All } \\
\text { misdemeanors } \\
\text { in superior } \\
\text { court, } \\
\text { nontraffic } \\
\text { misdemeanors } \\
\text { in lower } \\
\text { courts }\end{array}$ & $\begin{array}{l}\text { Caseloads of the Courts } \\
\text { of Washington, WASH. } \\
\text { CTS. (2017), } \\
\text { https://www.courts.wa. } \\
\text { gov/caseload/. }\end{array}$ & 42 \\
\hline Wis. & Statewide & $\begin{array}{l}\text { Total pretrial guilty plea } \\
\text { (51,374), divided by total } \\
\text { dispositions }(71,630) \text { (trial } \\
\text { outcomes are unknown but } \\
\text { still counted in total } \\
\text { dispositions). }\end{array}$ & All & $\begin{array}{l}\text { WIS. COURT SYS., } \\
\text { MISDEMEANOR } \\
\text { DISPOSITION SUMMARY } \\
\text { BY DISPOSING COURT } \\
\text { OFFICIAL STATEWIDE } \\
\text { REPORT (2018), } \\
\text { https://www.wicourts.g } \\
\text { ov/publications/statisti } \\
\text { cs/circuit/docs/misdem } \\
\text { eanorstate17.pdf. }\end{array}$ & 72 \\
\hline U.S. & Nationwide & $\begin{array}{l}\text { Data reports a conviction rate } \\
\text { of } 72.6 \% \text { of } 8,206 \text { dispositions. }\end{array}$ & All & $\begin{array}{l}\text { MARK MOTIVANS, U.S. } \\
\text { DEP'T OF JUSTICE, }\end{array}$ & 73 \\
\hline
\end{tabular}




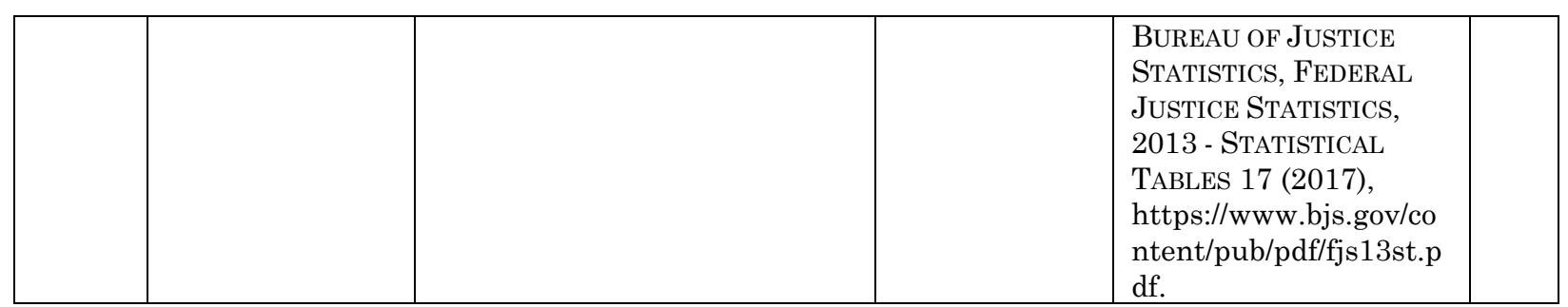

Notes:

For more information about variation in classification of traffic offenses as misdemeanors, see authority cited supra note 21.

A conviction of a misdemeanor, particularly those involving DUI and traffic laws, can be by trial, guilty plea, no contest plea, or "bail forfeiture" (also "bond forfeiture"). A few states reporting disposition information for misdemeanors include a disposition category termed "bail" or "bond forfeiture." When authority indicated this term was treated as a conviction in the state, we included these dispositions. 